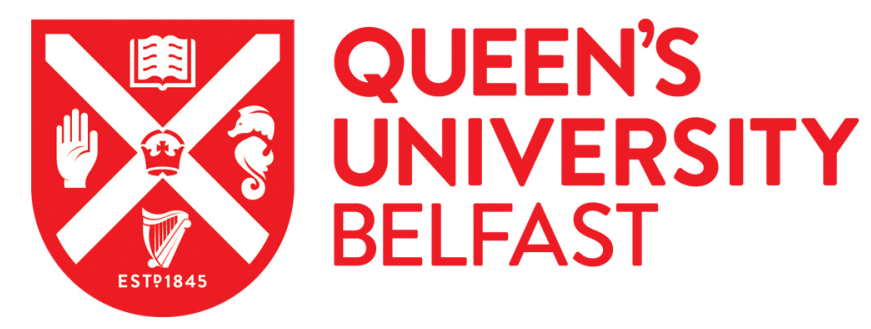

\title{
Effect of temperature on the strength development of mortar mixes with GGBS and fly ash
}

Soutsos, M., Hatzitheodorou, A., Kanavaris, F., \& Kwasny, J. (2017). Effect of temperature on the strength development of mortar mixes with GGBS and fly ash. Magazine of Concrete Research, 69(15), 787-801. https://doi.org/10.1680/jmacr.16.00268

Published in:

Magazine of Concrete Research

Document Version:

Peer reviewed version

Queen's University Belfast - Research Portal:

Link to publication record in Queen's University Belfast Research Portal

Publisher rights

(C) ICE Publishing 2017, all rights reserved.

This work is made available online in accordance with the publisher's policies. Please refer to any applicable terms of use of the publisher.

\section{General rights}

Copyright for the publications made accessible via the Queen's University Belfast Research Portal is retained by the author(s) and / or other copyright owners and it is a condition of accessing these publications that users recognise and abide by the legal requirements associated with these rights.

Take down policy

The Research Portal is Queen's institutional repository that provides access to Queen's research output. Every effort has been made to ensure that content in the Research Portal does not infringe any person's rights, or applicable UK laws. If you discover content in the Research Portal that you believe breaches copyright or violates any law, please contact openaccess@qub.ac.uk. 


\section{Effect of temperature on the strength development of mortar mixes with GGBS and fly ash.}

Marios Soutsos ${ }^{1 *}$ BEng (Hons), PhD, MICT

Professor of Structures/Materials, School of Natural and Built Environment, Queen's University Belfast, Northern Ireland, UK

Alexandros Hatzitheodorou ${ }^{2}$ BEng (Hons), MSc, PhD

Civil Engineer Consultant, Athens, Greece

Fragkoulis Kanavaris $^{3}$ MEng (Hons), AMICT, CAPM

$\mathrm{PhD}$ Researcher, School of Natural and Built Environment, Queen's University Belfast, Northern Ireland, UK

Jacek Kwasny ${ }^{4}$ BScEng, MSc, $\mathrm{PhD}$

Research Fellow, School of Natural and Built Environment, Queen's University Belfast, Northern Ireland, UK

${ }^{1}$ m.soutsos@qub.ac.uk (* corresponding author)

2 alexengineer30@gmail.com

${ }^{3}$ fkanavaris01@qub.ac.uk

4j.kwasny@qub.ac.uk

No. of words in main text: 3,511

No. of figures: 15

No. of tables: 4 


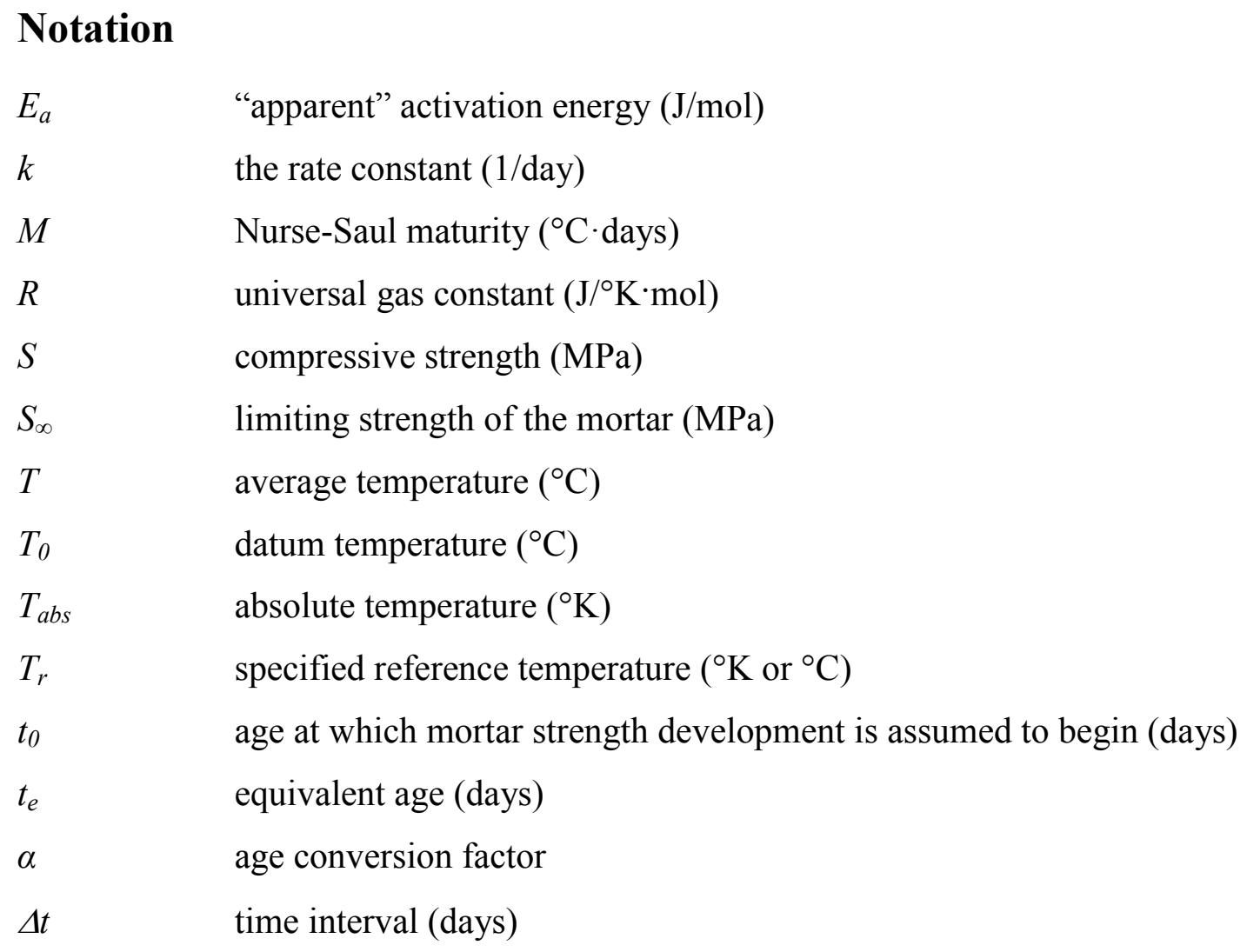




\begin{abstract}
The concrete mixes used were of 28-day mean strengths of 50 and $30 \mathrm{MPa}$ and also had partial Portland cement (PC) replacement with ground granulated blast-furnace slag (GGBS) and fly ash (FA). These mixes were the ones used in a UK based project which involved casting of blocks, walls and slabs. The strength development of "equivalent" mortar mixes was determined in the laboratory for curing temperatures of 10, 20, 30, 40 and $50{ }^{\circ} \mathrm{C}$. High curing temperatures have a beneficial effect on the early age strength but a detrimental effect on the long term strength. GGBS has been shown to be more sensitive to high curing temperatures than PC and FA and this is reflected in its higher "apparent" activation energy. The accuracy of strength estimates obtained from maturity functions was examined. The temperature dependence of the Nurse-Saul function, i.e. the concrete strength gain rate varies linearly with temperature, was not sufficient to account for the improvement in early age strengths resulting from high curing temperatures. The Arrhenius based function, on the other hand, overestimated them because of the detrimental effect of high curing temperature on strength starting from a very early age. Both functions overestimate long term strengths as neither accounts for the detrimental effect of high curing temperatures on the ultimate compressive strength.
\end{abstract}

\title{
Keywords
}

Compressive strength, Cement/cementitious materials, Temperature-related \& thermal effects 


\section{$1 \quad$ Introduction}

Portland cement in combination with ground granulated blast-furnace slag (GGBS) and fly ash (FA) is commonly used for many concretes (Bijen, 1996; ACI Committee 233, 2003; Ling et al., 2006; Won et al., 2015; Berndt, 2015; Golden and Wong, 2016). Use of GGBS and FA offers advantages like improved durability and workability and has even economic benefits (ACI 233R-03, 2003; Tang et al., 2013; Thomas, 2013). However, the strength development of concretes with partial cement replacement with GGBS and FA is considerably slower under standard $20^{\circ} \mathrm{C}$ curing conditions than that of neat Portland cement concrete. This is despite that the ultimate strength is higher for the same water to binder (w/b) ratio (Roy and Idorn, 1982; Escalante-Garcia and Sharp, 2001; Escalante-Garcia et al., 2001; Barnett et al., 2007a; Barnett et al., 2007b). The use of GGBS and FA in applications where high early age strength is required tends to be avoided. However, the strength development of concretes with GGBS and FA is significantly enhanced at higher early age temperatures as the reactions of GGBS and FA is much more sensitive to temperature than Portland cement (Roy and Idorn, 1982; Escalante-Garcia et al., 2001). There can be a significant rise in temperature within the first few days after casting of large structural concrete elements where heat dissipation is slow and heat from the exothermic reaction of the binder cannot be dissipated quickly (Sanjayan and Sioulas, 2000; Yikici et al., 2015; Soutsos et al., 2016). Higher

early age strengths are therefore expected and these can only be determined by temperature matched curing. Cubes or cylinders cured at $20^{\circ} \mathrm{C}$, or adjacent to the structure, would underestimate the strength in the structure.

Concrete mixture composition, including factors such as w/b ratio and the use of GGBS and FA affect the early age strength development of concrete as is the type of formwork and size of structural element, and the ambient temperature. All these factors formed part of a DTI Concrete Core Project (The Concrete Society, 2004), which involved casting concrete blocks, walls and slabs, see Figure 1, with neat Portland cement and partial cement replacement with GGBS and FA. The DTI project was designed to provide the information needed to enable the potential strength of concretes with GGBS and FA to be derived, taking into account age at test, thermal history, cement type and 
concrete strength. The data generated has been very extensive although aimed at longterm rather than early-age strength determination. The concrete mixes used in the DTI project, were replicated in the laboratory (Soutsos et al., 2016) in order to determine the effect of temperature on their early-age strength development. Variables investigated were nominal concrete compressive strength (50 $\mathrm{MPa}$ and $30 \mathrm{MPa})$ and partial cement replacement with GGBS and FA. Results on the effect of in situ temperature history on the strength development were reported in Soutsos et al., 2016. The work reported here formed the second phase of the project which investigated the effect of curing temperature, i.e. $10,20,30,40$ and $50{ }^{\circ} \mathrm{C}$, on the strength development of equivalent mortars. Determination of the strength development of equivalent mortars enabled the initial "apparent" activation energies to be calculated.

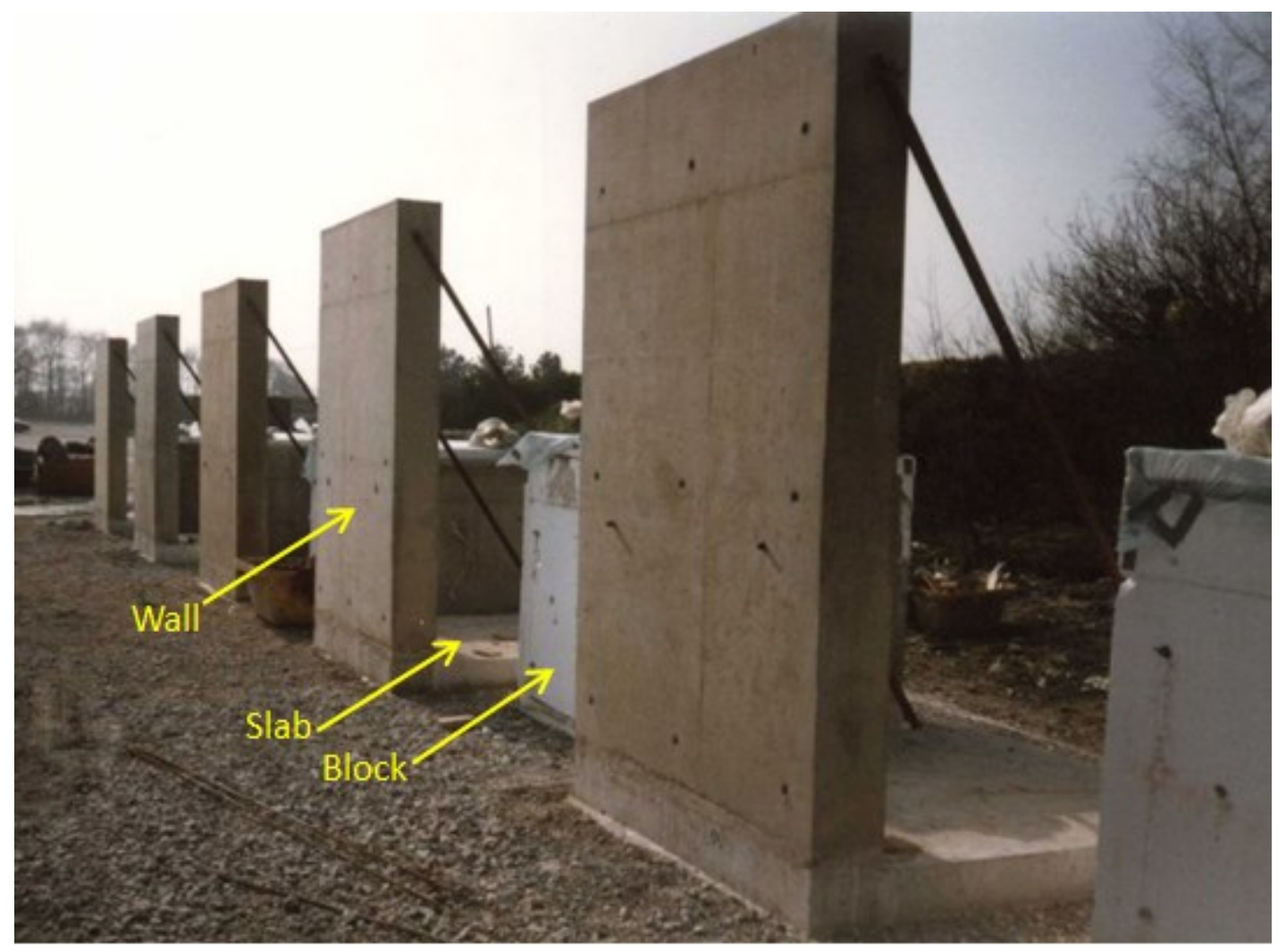

Figure 1: $\quad$ Structural elements cast during the DTI project (The Concrete Society, 2004).

The "apparent" activation energies determined were used in maturity functions, like the Arrhenius function, for estimating the in situ strength development of concrete and they 
have been reported in Soutsos et al., 2016. These can also be used for estimating the strength development of mortars under isothermal curing regimes. The applicability/accuracy of the Nurse-Saul function for estimating the effect of curing temperatures on the strength development was also investigated despite that this does not require the determination of the "apparent" activation energies.

\section{Materials and experimental procedures}

Only equivalent mortars to concrete mixes used in DTI project (Hatzitheodorou, 2007; Soutsos et al., 2016) have been investigated. The mix proportions of these mortars were determined according to ASTM C1074-11 (ASTM, 2011) based on the mix proportions of the corresponding concretes. The ASTM C1074-11 (ASTM, 2011) requirements were for the mortars to have the same water-binder $(\mathrm{w} / \mathrm{b})$ ratio as the concrete and the fine aggregate to binder ratio to be equal to the coarse aggregate to binder ratio of the concrete. The resulting mortar mixture proportions are shown in Table 1, alongside the concrete mixes. 
Table 1: Mix proportions of concrete of strength of $50 \mathrm{MPa}$ and $30 \mathrm{MPa}$ (Soutsos et al., 2016) and their equivalent mortars.

\begin{tabular}{|c|c|c|c|c|c|c|c|c|c|c|c|c|}
\hline Mix ID & & & & 550 & & & & & & $S 30$ & & 30 \\
\hline Material & Uूँ & 离 & Uूँ & 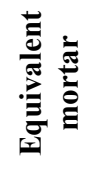 & 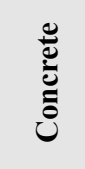 & 莺 & Uूँ & 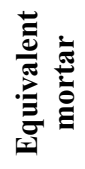 & 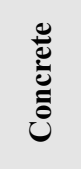 & 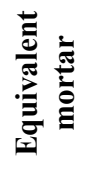 & 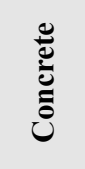 & 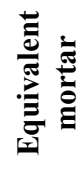 \\
\hline $\mathrm{PC}\left[\mathrm{kg} / \mathrm{m}^{3}\right]$ & 345 & 442 & 165 & 219 & 270 & 332 & 240 & 348 & 115 & 160 & 193 & 239 \\
\hline GGBS $\left[\mathrm{kg} / \mathrm{m}^{3}\right]$ & - & - & 165 & 219 & - & - & - & - & 115 & 160 & - & - \\
\hline FA $\left[\mathbf{k g} / \mathbf{m}^{3}\right]$ & - & - & - & - & 115 & 141 & - & - & - & - & 82 & 102 \\
\hline Gravel $\left[\mathrm{kg} / \mathrm{m}^{3}\right]$ & 1205 & - & 1151 & - & 1250 & - & 1102 & - & 1187 & - & 1319 & - \\
\hline Sand $\left[\mathrm{kg} / \mathrm{m}^{3}\right]$ & 615 & 1519 & 683 & 1588 & 533 & 1523 & 799 & 1583 & 721 & 1547 & 560 & 1633 \\
\hline $\begin{array}{l}\text { Free water } \\
{\left[\mathrm{kg} / \mathrm{m}^{3}\right]}\end{array}$ & 160 & 204 & 165 & 200 & 135 & 166 & 158 & 229 & 150 & 208 & 144 & 180 \\
\hline $\begin{array}{l}\text { Total water } \\
{\left[\mathrm{kg} / \mathrm{m}^{3}\right]}\end{array}$ & 197 & 244 & 203 & 241 & 171 & 207 & 198 & 271 & 190 & 252 & 181 & 224 \\
\hline Free w/b [-] & 0.46 & 0.46 & 0.50 & 0.46 & 0.35 & 0.35 & 0.66 & 0.66 & 0.65 & 0.65 & 0.52 & 0.53 \\
\hline Total w/b [-] & 0.57 & 0.55 & 0.62 & 0.55 & 0.44 & 0.44 & 0.83 & 0.78 & 0.83 & 0.79 & 0.66 & 0.66 \\
\hline $\begin{array}{l}\text { Concrete } \\
\text { slump [mm] }\end{array}$ & 135 & - & 120 & - & 10 & - & 150 & - & 120 & - & 120 & - \\
\hline
\end{tabular}

\subsection{Materials}

Portland cement (PC) CEMI 52.5N with standard strength of $57 \mathrm{MPa}$ (determined based on BS EN 196-1:2005 (BSI, 2005)) and that conformed to BS EN 197-1:2011 (BSI, 2011) was supplied by British Lime Industries who were also the supplier of the PC for the DTI project. PC composition variations may have however existed since this research project started years after the DTI project had been completed. PC was partially replaced with GGBS and FA conforming to BS EN 15167-1:2006 (BSI, 2006) and BS EN 450-1:2012 (BSI, 2012), respectively. GGBS was supplied by Appleby Group whereas FA was supplied in by Fiddlers Ferry, a coal-fired electricity-generating station, in Warrington, UK. The chemical compositions of PC, GGBS and FA are shown in Table 2. 
Table 2: $\quad$ Chemical composition of $P C, G G B S$ and $F A$.

\begin{tabular}{|c|c|c|c|}
\hline \multicolumn{5}{|c|}{ Chemical composition (\% by weight) } \\
\hline $\begin{array}{c}\text { Chemical } \\
\text { constituent }\end{array}$ & PC & GGBS & FA \\
\hline $\mathrm{SiO}_{2}$ & 20.11 & 35.35 & 48 \\
\hline $\mathrm{Al}_{2} \mathrm{O}_{3}$ & 5.16 & 14 & 27 \\
\hline $\mathrm{Fe}_{2} \mathrm{O}_{3}$ & 3.14 & 0.36 & 9 \\
\hline $\mathrm{CaO}$ & 65.49 & 41.41 & 3.3 \\
\hline $\mathrm{MgO}$ & 0.8 & 7.45 & 2 \\
\hline $\mathrm{SO}_{3}$ & 3.22 & 0.1 & 0.6 \\
\hline $\mathrm{K}_{2} \mathrm{O}$ & 0.59 & - & 3.8 \\
\hline $\mathrm{Na}_{2} \mathrm{O}$ & 0.13 & - & 1.2 \\
\hline $\mathrm{CaCO}_{3}$ & 4.47 & - & - \\
\hline $\begin{array}{c}\text { Equiv. Alks } \\
\mathrm{Na}_{2} \mathrm{Oe}\end{array}$ & 0.52 & - & - \\
\hline Free $\mathrm{Lime}$ & 1.79 & - & - \\
\hline \begin{tabular}{c}
$\mathrm{Chloride}$ \\
\hline
\end{tabular} & $71 \mathrm{ppm}$ & - & - \\
\hline
\end{tabular}

The coarse aggregate used for the laboratory replicated concrete mixes (Soutsos et al., 2016), shown in Table 1, was 5-20 mm uncrushed round gravel from the Fagl Lane quarry, which is located in Wales. Its specific gravity and water absorption were 2.6 and $1.7 \%$, respectively. The fine aggregate used for the concrete mixes and the equivalent mortar mixes was fine sand obtained from the Fagl Lane quarry. It was considered to be fine according to BS 882:1992 (BSI, 1992) that was in use at the time of the DTI project. The sand would not comply with the new BS EN 12620:2002+A1:2008 (BSI, 2002). The sand had a specific gravity of 2.60 and water absorption of $2.6 \%$. The grading for both coarse and fine aggregate is shown in Figure 2. 


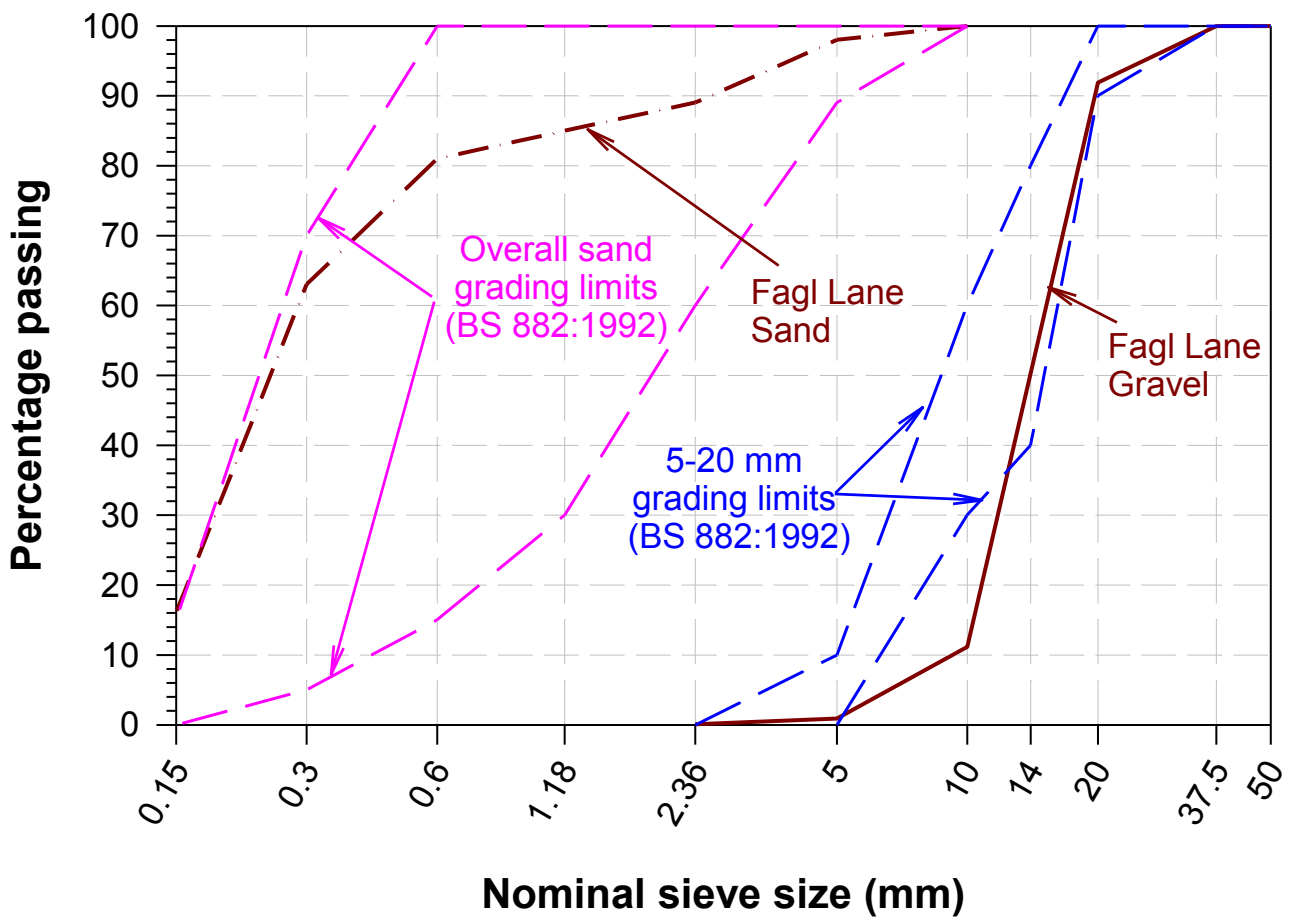

Figure 2: $\quad$ Sieve analysis of coarse and fine aggregate used.

\subsection{Mixing, casting, curing and testing procedures}

A horizontal pan mixer was used and the materials were added in the order: PC, GGBS or FA, sand and water. Quantities of mortar were $0.015 \mathrm{~m}^{3}$ each time. Mixing was for 3 minutes after which the mortar was cast into steel $50 \mathrm{~mm}$ cube moulds consolidated on a vibrating table and wrapped in polyethylene film which ensured that they were sealed, to stop wash out when they were transferred to water tanks for curing at 20,30,40 and $50{ }^{\circ} \mathrm{C}$. For curing at $10{ }^{\circ} \mathrm{C}$, the specimens were wrapped in damp hessian and stored in an incubator. They were demoulded at the time of the first compressive strength test. Three cubes were tested at six to eight testing ages for each mixture/temperature combination. In each case, the first testing age corresponded to a compressive strength of approximately $4 \mathrm{MPa}$, achieved by trial and error and subsequent tests were carried out at twice the age of the previous test. 


\section{$3 \quad$ Results and discussion}

The first part of the work involved "equivalent" mortars and their strength development is compared to the corresponding concretes. The second part was the investigation of the strength development at elevated curing temperatures. These were used in the third part for determining the "apparent" activation energies. The fourth part uses the NurseSaul and Arrhenius functions for estimating the strength development at elevated curing temperatures. The accuracy of these maturity functions was therefore investigated.

\subsection{Strength development of concretes and their equivalent mortars}

The determination of "apparent" activation energies, according to ASTM Standard C1074-11 (ASTM, 2011), requires monitoring of the strength development of "equivalent" mortars. These need to have the same w/b ratio as the concretes. The sand to binder ratios need to be equal to the coarse aggregate to binder ratios of the concretes. The mix proportions of the equivalent mortars, shown in Table 1, have been calculated from those of the corresponding concretes which are also shown in Table 1.

According to ASTM Standard C1074-11 (ASTM, 2011), tests can be performed on mortar specimens and the "apparent" activation energies applied to the concretes under investigation. The strength development at $20^{\circ} \mathrm{C}$ of concretes and their equivalent mortars are shown in Figure 3 for both $50 \mathrm{MPa}$ and $30 \mathrm{MPa}$. The strengths at very early ages are similar between concretes and mortars. However, there are differences in strengths at later ages and these increase with age. These are small for mortar and concretes of $50 \mathrm{MPa}$ strength but considerable for those of $30 \mathrm{MPa}$. There is also no consistent trend as to which has the higher strength, i.e. concrete or mortar. GGBS and $\mathrm{PC}$ concrete strengths are lower for both 50 and $30 \mathrm{MPa}$ compressive strengths. On the other hand, the FA concretes have higher compressive strengths than their equivalent mortars. 


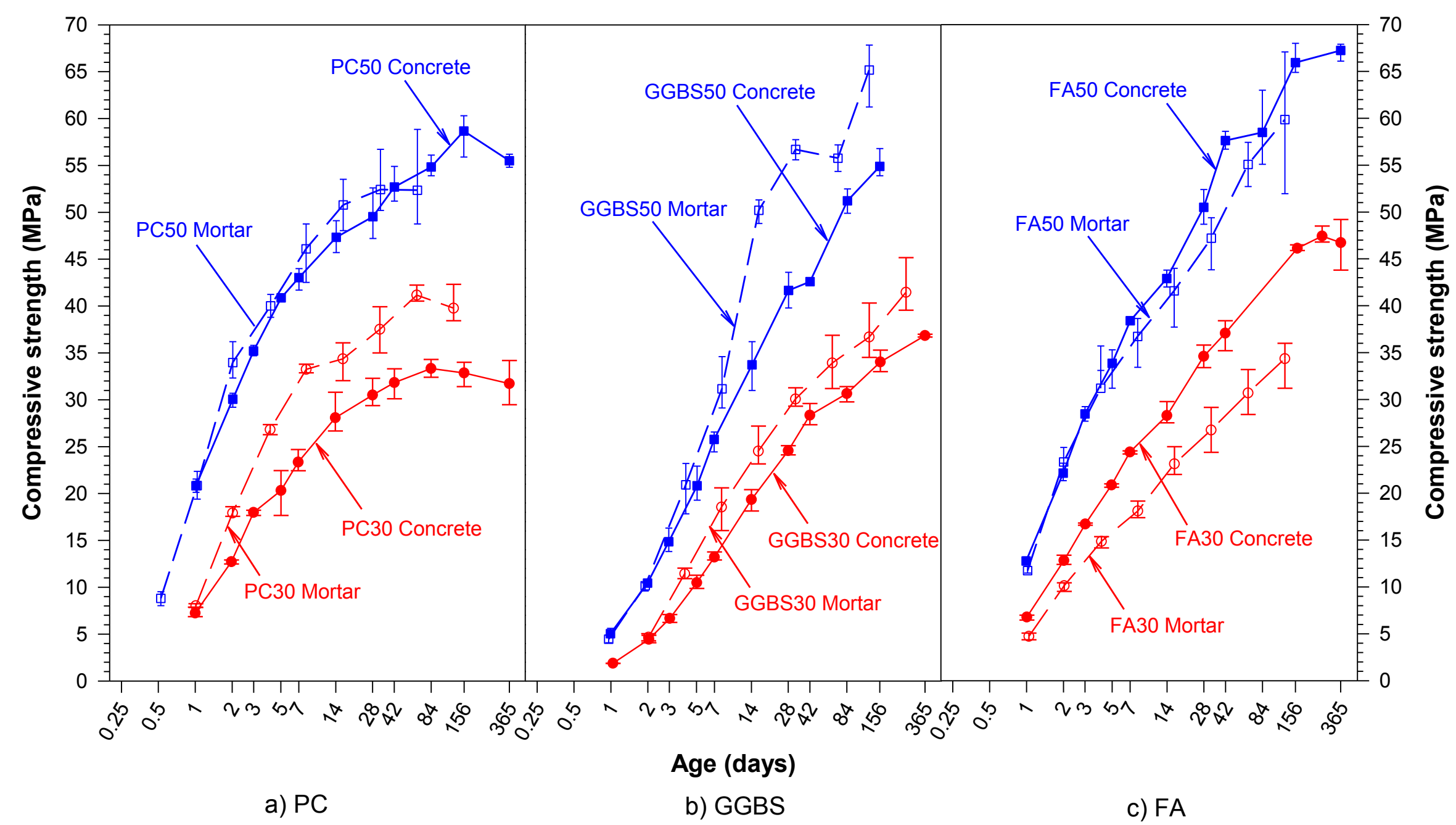

Figure 3: $\quad$ Comparison of strength development of concretes of strength 50 and $30 \mathrm{MPa}$ and their equivalent mortars. 


\subsection{Effect of temperature on mortar strength development}

The development of compressive strength, $S$, at a given curing temperature, can be described as a function of time, $t$, by the equation (Tank and Carino, 1991; Soutsos et al., 2005):

$$
S=\frac{S_{\infty} \cdot k \cdot\left(t-t_{0}\right)}{1+k \cdot\left(t-t_{0}\right)}
$$

\section{Equation 1}

where: $\quad S_{\infty} \quad$ is the limiting strength of the mortar (MPa),

$k \quad$ is the rate constant at temperature $T(1 /$ day),

$t \quad$ is the test age (days),

$t_{0} \quad$ is the age at which mortar strength development is assumed to begin at temperature $T$ (days).

This equation was used to obtain regression lines through the strength data and the regression constants for all the mixes are shown in Table 3. 
Table 3: $\quad$ Regression constants for strength-time relationship (Equation 1).

\begin{tabular}{|c|c|c|c|c|c|c|c|c|c|c|c|c|c|c|c|c|c|c|c|}
\hline \multirow{2}{*}{\multicolumn{2}{|c|}{$\begin{array}{r}\text { Mix ID } \\
\text { Regression } \\
\text { constants }\end{array}$}} & \multicolumn{3}{|c|}{ PC50 } & \multicolumn{3}{|c|}{ GGBS50 } & \multicolumn{3}{|c|}{ FA50 } & \multicolumn{3}{|c|}{ PC30 } & \multicolumn{3}{|c|}{ GGBS30 } & \multicolumn{3}{|c|}{ FA30 } \\
\hline & & $\mathbf{S}_{\mathbf{u}}$ & $\mathbf{k}$ & $\mathbf{t}_{0}$ & $\mathbf{S}_{\mathbf{u}}$ & k & $\mathbf{t}_{0}$ & $\mathbf{S}_{\mathbf{u}}$ & $\mathbf{k}$ & $\mathbf{t}_{0}$ & $\mathbf{S}_{\mathbf{u}}$ & $\mathrm{k}$ & $\mathbf{t}_{0}$ & $\mathbf{S}_{\mathbf{u}}$ & $\mathbf{k}$ & $\mathbf{t}_{0}$ & $\mathbf{S}_{\mathbf{u}}$ & $\mathbf{k}$ & $\mathbf{t}_{0}$ \\
\hline \multirow{5}{*}{ 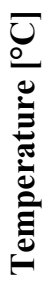 } & 10 & 56.7 & 0.45 & $4.56 \mathrm{E}-01$ & 66.4 & 0.08 & $6.73 \mathrm{E}-01$ & 58.9 & 0.18 & $1.91 \mathrm{E}-01$ & 45.1 & 0.28 & 8.02E-01 & 44.3 & 0.04 & $3.41 \mathrm{E}-01$ & 31.3 & 0.15 & $1.99 \mathrm{E}-01$ \\
\hline & 20 & 53.6 & 0.89 & 3.03E-01 & 67.1 & 0.14 & $5.66 \mathrm{E}-01$ & 56.8 & 0.26 & 4.44E-09 & 40.5 & 0.54 & 5.49E-01 & 40.8 & 0.10 & 4.09E-01 & 33.8 & 0.16 & $4.89 \mathrm{E}-09$ \\
\hline & 30 & 52.9 & 0.98 & 4.66E-02 & 62.4 & 0.35 & $4.18 \mathrm{E}-01$ & 65.2 & 0.33 & 4.38E-09 & 38.1 & 0.80 & $2.22 \mathrm{E}-02$ & 33.9 & 0.35 & 4.87E-01 & 37.0 & 0.17 & $1.52 \mathrm{E}-08$ \\
\hline & 40 & 44.4 & 1.67 & $5.18 \mathrm{E}-10$ & 59.4 & 0.46 & $1.66 \mathrm{E}-01$ & 54.6 & 0.52 & $2.71 \mathrm{E}-09$ & 34.8 & 1.21 & 4.09E-02 & 33.1 & 0.41 & $1.36 \mathrm{E}-01$ & 38.5 & 0.30 & 3.74E-09 \\
\hline & 50 & 38.1 & 2.32 & $1.97 \mathrm{E}-09$ & 51.1 & 0.72 & $1.24 \mathrm{E}-01$ & 51.7 & 0.78 & $6.07 \mathrm{E}-10$ & 27.7 & 2.22 & 4.47E- 02 & 32.8 & 0.56 & $1.41 \mathrm{E}-01$ & 32.4 & 0.48 & $6.94 \mathrm{E}-11$ \\
\hline \multicolumn{2}{|c|}{$\begin{array}{c}\mathbf{E}_{\mathbf{a}} \\
{[\mathrm{kJ} / \mathrm{mol}]}\end{array}$} & \multicolumn{3}{|c|}{29.7} & \multicolumn{3}{|c|}{41.6} & \multicolumn{3}{|c|}{27.3} & \multicolumn{3}{|c|}{37.4} & \multicolumn{3}{|c|}{53.3} & \multicolumn{3}{|c|}{22.5} \\
\hline
\end{tabular}


The compressive strength development with age at different curing temperatures is shown in Figures 4 and 5 for strengths of 50 and $30 \mathrm{MPa}$, respectively. As expected, the strength development of all the mortars depended on the curing temperature. At early ages, the strength was higher at higher temperatures since the rate of reaction is greater. At later ages, the strength was lower at high curing temperatures. This is believed to be due to the formation of dense hydrated phases around the unreacted cement particles, preventing further hydration (Escalante-Garcia and Sharp, 2001; Escalante-Garcia and Sharp, 1997). The non-uniform distribution of hydration products also leads to larger pores in the microstructure. The mortars containing GGBS were more sensitive on temperature, with the early age strengths showing a wider variation with temperature. 


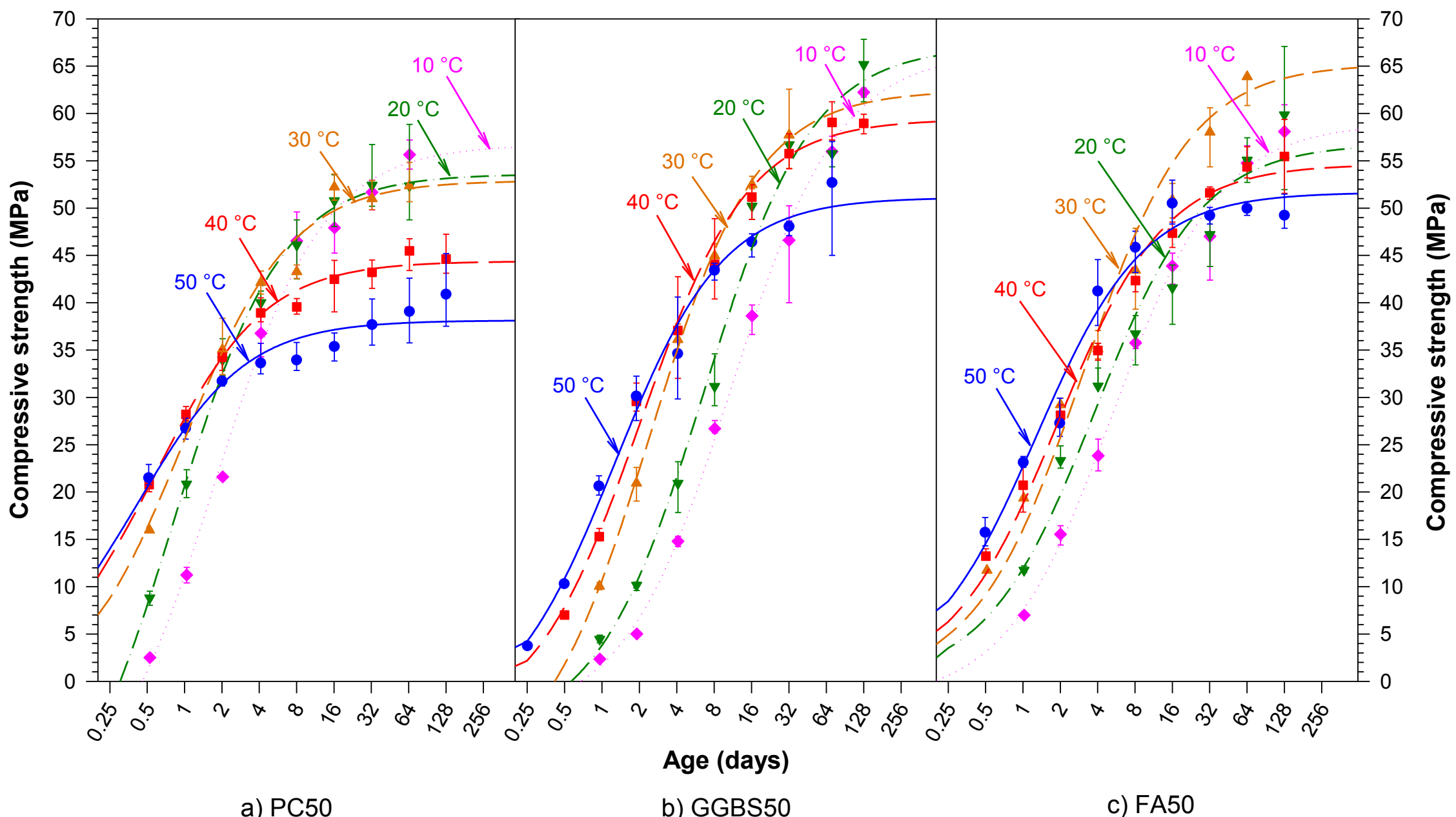

Figure 4: $\quad$ Strength versus age for mortars with strength of $50 \mathrm{MPa}$. 


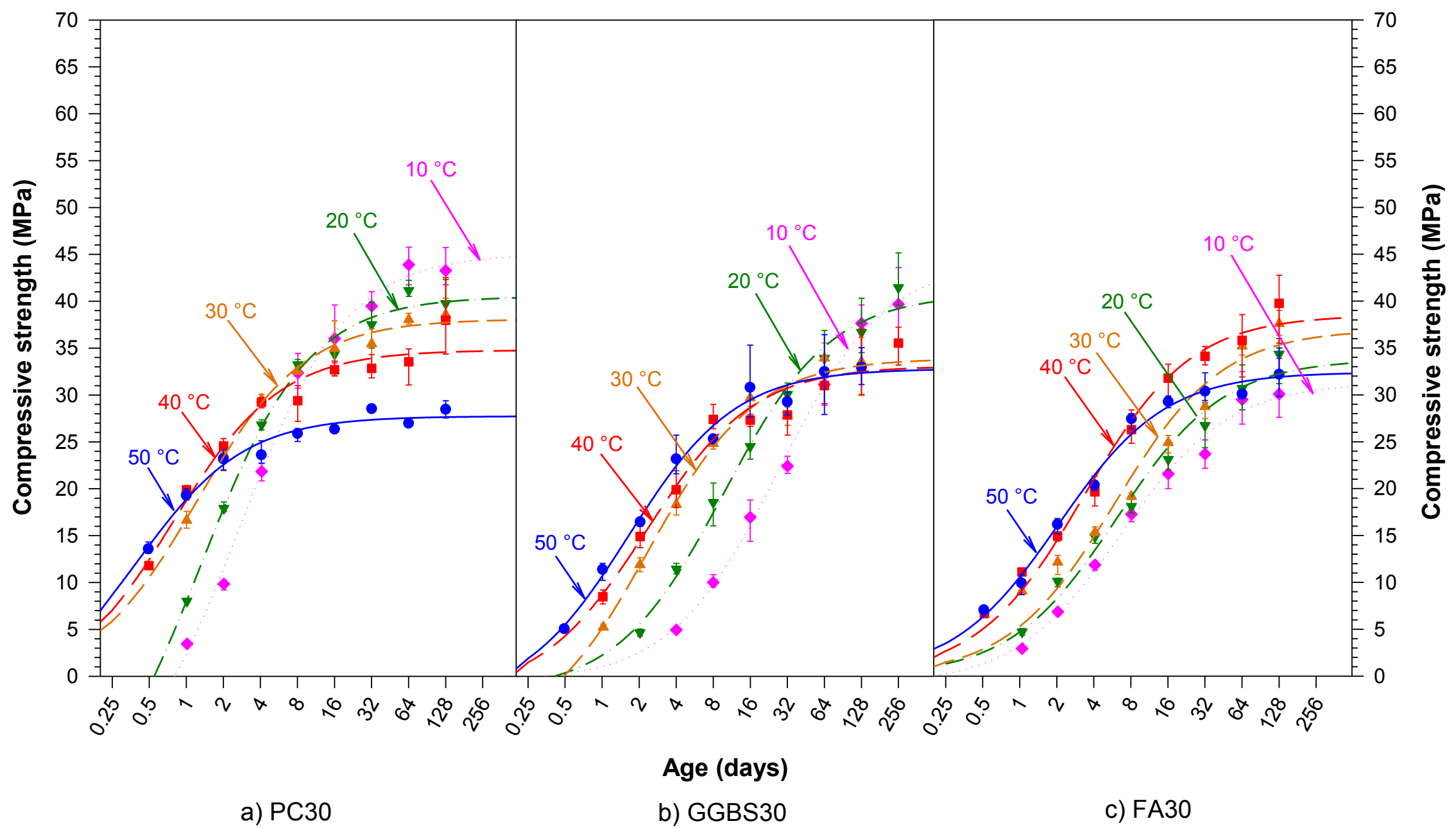

Figure 5: $\quad$ Strength versus age for mortars with strength of $30 \mathrm{MPa}$. 
The relative strengths, i.e. the strength ratio of actual strength to that at $20^{\circ} \mathrm{C}$ curing strength, are shown in Figures 6 and 7 for strengths of 50 and $30 \mathrm{MPa}$, respectively. These figures clearly show the benefit of higher curing temperatures on the early age strength development of mortars, especially those containing GGBS. Strength ratios of actual strengths with $20^{\circ} \mathrm{C}$ curing strength for GGBS were as high as 4.63 at 1-day and 3.53 at 2-days for 50 and $30 \mathrm{MPa}$ equivalent mortars respectively. These were much higher from the 1.28 and 1.29 for corresponding PC mortars. 


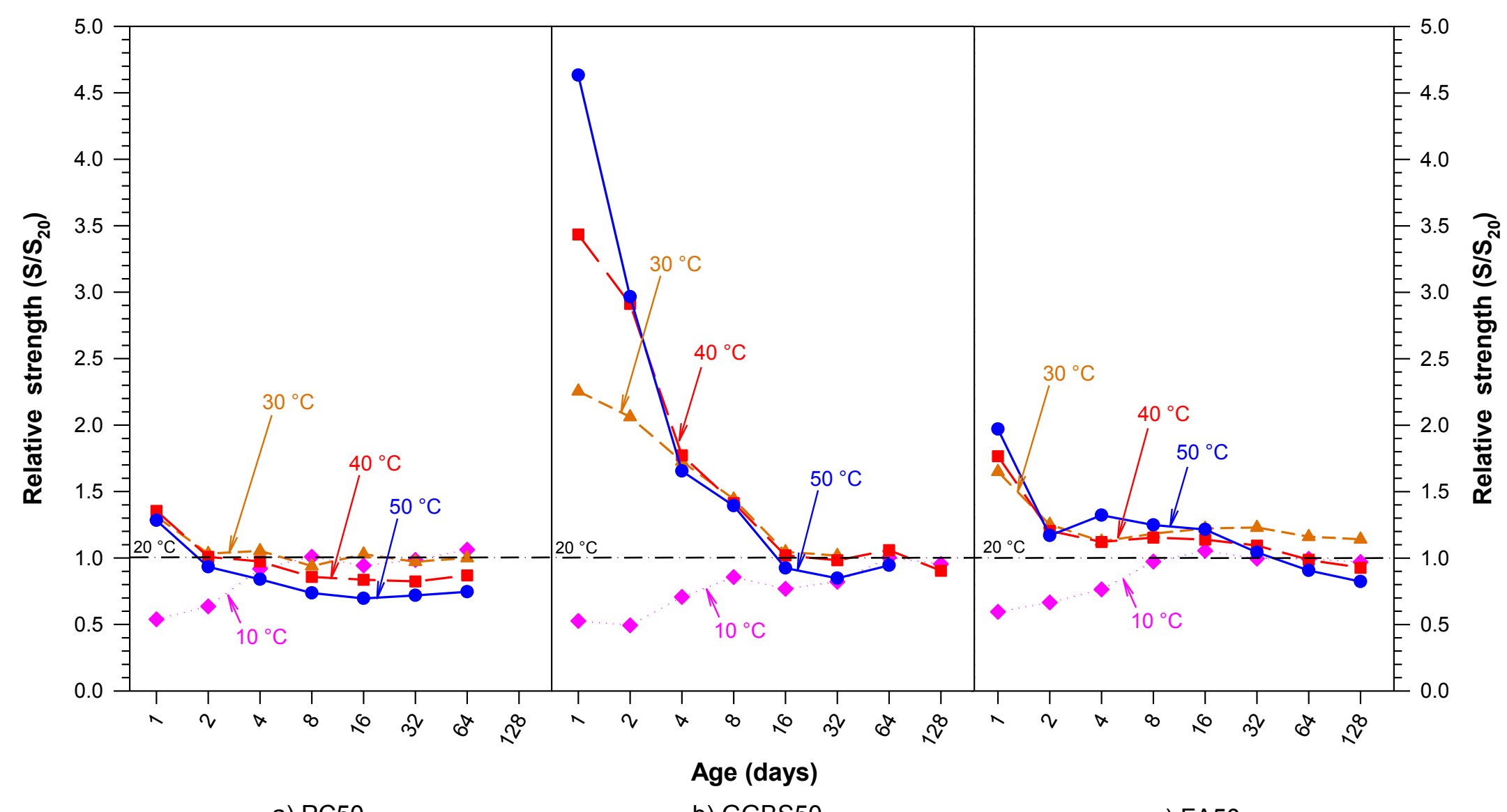
a) PC50
b) GGBS50
c) FA50

Figure 6: Relative strengths, i.e. strength ratio of actual strengths $(S)$ with $20^{\circ} \mathrm{C}$ curing strengths $\left(S_{20}\right)$, for mortars with strength of $50 \mathrm{MPa}$. 


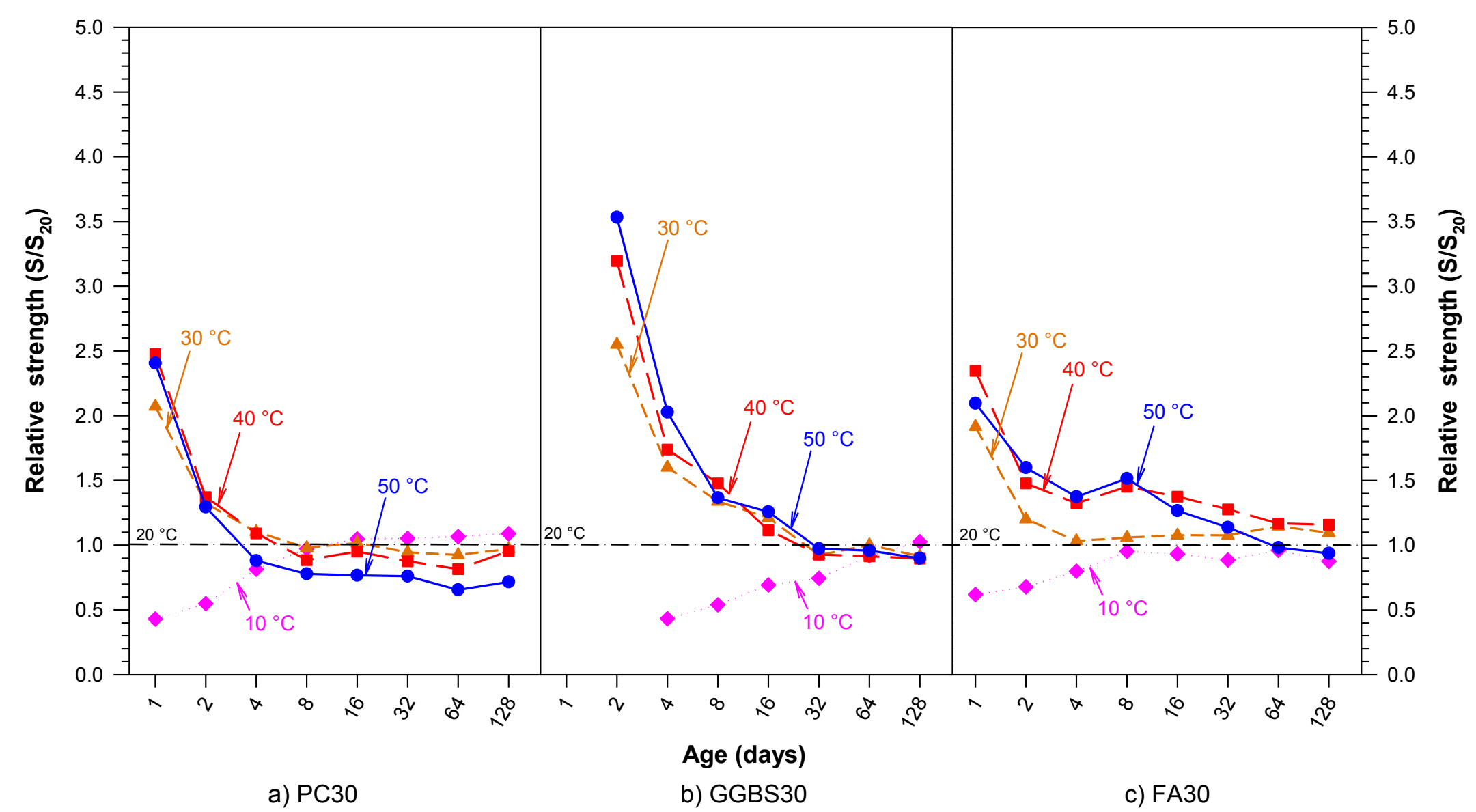

Figure 7: Relative strengths, i.e. strength ratio of actual strengths $(S)$ with $20^{\circ} \mathrm{C}$ curing strengths $\left(S_{20}\right)$, for mortars with strength of $30 \mathrm{MPa}$. 


\subsection{Determination of "apparent" activation energies}

There are a number of functions available to describe the variation of the rate constant $k$ with temperature. The Nurse-Saul maturity model (Nurse, 1949; Saul, 1951):

$$
M=\sum_{t}\left(T-T_{0}\right) \cdot \Delta t
$$

Equation 2

assumes a linear relationship:

$$
k_{N S}=a \cdot\left(T-T_{0}\right)
$$

Equation 3

where: $\quad \mathrm{M} \quad$ is the Nurse-Saul maturity $\left({ }^{\circ} \mathrm{C} \cdot\right.$ days $)$,

$\mathrm{T} \quad$ is the average temperature $\left(20^{\circ} \mathrm{C}\right.$ for standard curing) over the time interval $\Delta \mathrm{t}\left({ }^{\circ} \mathrm{C}\right)$,

$\mathrm{T}_{0} \quad$ is the datum temperature $\left({ }^{\circ} \mathrm{C}\right)$,

$\Delta \mathrm{t} \quad$ is the time interval (days),

$\mathrm{k}_{\mathrm{NS}}$ is the rate constant,

a is a constant $\left(1 /{ }^{\circ} \mathrm{C}\right)$.

The datum temperature is the temperature below which it is assumed that no strength gain will occur, taken as $-11{ }^{\circ} \mathrm{C}$ in this work which is the average of what is recommended in the literature, i.e. between $-10{ }^{\circ} \mathrm{C}$ and $-12{ }^{\circ} \mathrm{C}$ (Han, 2005; Malhotra, 2006; Gambhir, 2013). The relationship between strength and maturity is assumed to be independent of temperature history, and can therefore be determined at a reference temperature. An equivalent age, $t_{e}$, can be defined as the age at the reference temperature at which the concrete has the same strength as at a time $t$ :

$$
t_{e}=\frac{\sum\left(T-T_{0}\right)}{\left(T_{r}-T_{0}\right)} \cdot \Delta t
$$

where: $t_{e}$ is the equivalent age at the reference temperature (days), 
$\mathrm{T}_{\mathrm{r}} \quad$ is the reference temperature $\left({ }^{\circ} \mathrm{C}\right)$.

Equation 4 can be written as follows (Carino, 2004):

$$
t_{e}=\sum \alpha \cdot \Delta t
$$

Equation 5

and the age conversion factor, $\alpha$, is:

$$
\alpha=\frac{T-T_{0}}{T_{r}-T_{0}}
$$

Equation 6

where: $\quad t_{e} \quad$ is the equivalent age at the reference temperature (days),

$\mathrm{T}_{\mathrm{r}} \quad$ is the reference temperature $\left({ }^{\circ} \mathrm{C}\right)$,

$\mathrm{T} \quad$ is the average temperature $\left(20^{\circ} \mathrm{C}\right.$ for standard curing $)$ over the time interval $\Delta \mathrm{t}\left({ }^{\circ} \mathrm{C}\right)$,

$\mathrm{T}_{0} \quad$ is the datum temperature $\left({ }^{\circ} \mathrm{C}\right)$,

$\alpha \quad$ is the age conversion factor.

The ratio $\alpha$, which is called the "age conversion factor", has a simple interpretation: it converts a curing interval $\Delta t$ to the equivalent curing interval at the reference temperature (Carino, 2004).

The assumption that the rate of strength development obeys the Arrhenius equation leads to the maturity function (referred to as Arrhenius function in this paper):

$$
t_{e}=\sum e^{-\frac{E_{a}}{R} \cdot\left(\frac{1}{T_{a}}-\frac{1}{T_{s}}\right)} \cdot \Delta t
$$

where: $t_{e}$ is the equivalent age (days),

$\mathrm{T}_{\mathrm{a}}$ is the average temperature of concrete during time interval $\Delta \mathrm{t}(\mathrm{K})$,

$\mathrm{T}_{\mathrm{S}}$ is the specified reference temperature $(\mathrm{K})$, 
$E_{a}$ is the "apparent" activation energy $(\mathrm{J} / \mathrm{mol})$,

$\mathrm{R}$ is the universal gas constant $(\mathrm{J} / \mathrm{K} \cdot \mathrm{mol})$.

In this case the age conversion factor is:

$$
\alpha=e^{-\frac{E_{a}}{R}\left(\frac{1}{T_{r}}-\frac{1}{T}\right)} .
$$

\section{Equation 8}

In order to calculate the "apparent" activation energy, $E_{a}$, the ASTM C1074-11 recommendation (ASTM, 2011) is to plot $\ln (k)$, obtained from Equation 1 and shown in Table 3, against $1 / T_{a b s}$ (given in $1 /$ Kelvin), where $T_{a b s}$ is the absolute curing temperature. The negative of the slope of the line, $-Q$, is the "apparent" activation energy, $E_{a}$, divided by the universal gas constant, $R$ (equal to $8.31 \mathrm{~J} / \mathrm{K} \cdot \mathrm{mol}$ gas), i.e. $-Q$ $=E_{a} / R$ or $E_{a}=-Q \cdot R$. The plots of $\ln (k)$ versus $1 / T_{a b s}$ are shown in Figure 8 and $E_{a}$, obtained are shown in Figure 9. GGBS mixes appear to have higher "apparent" activation energies than PC mixes. FA mixes on the other hand appear to be slightly lower than PC mixes. The effect of temperature on the strength gain rate becomes more apparent when the age conversion factor is plotted against temperature, see Figure 10. 


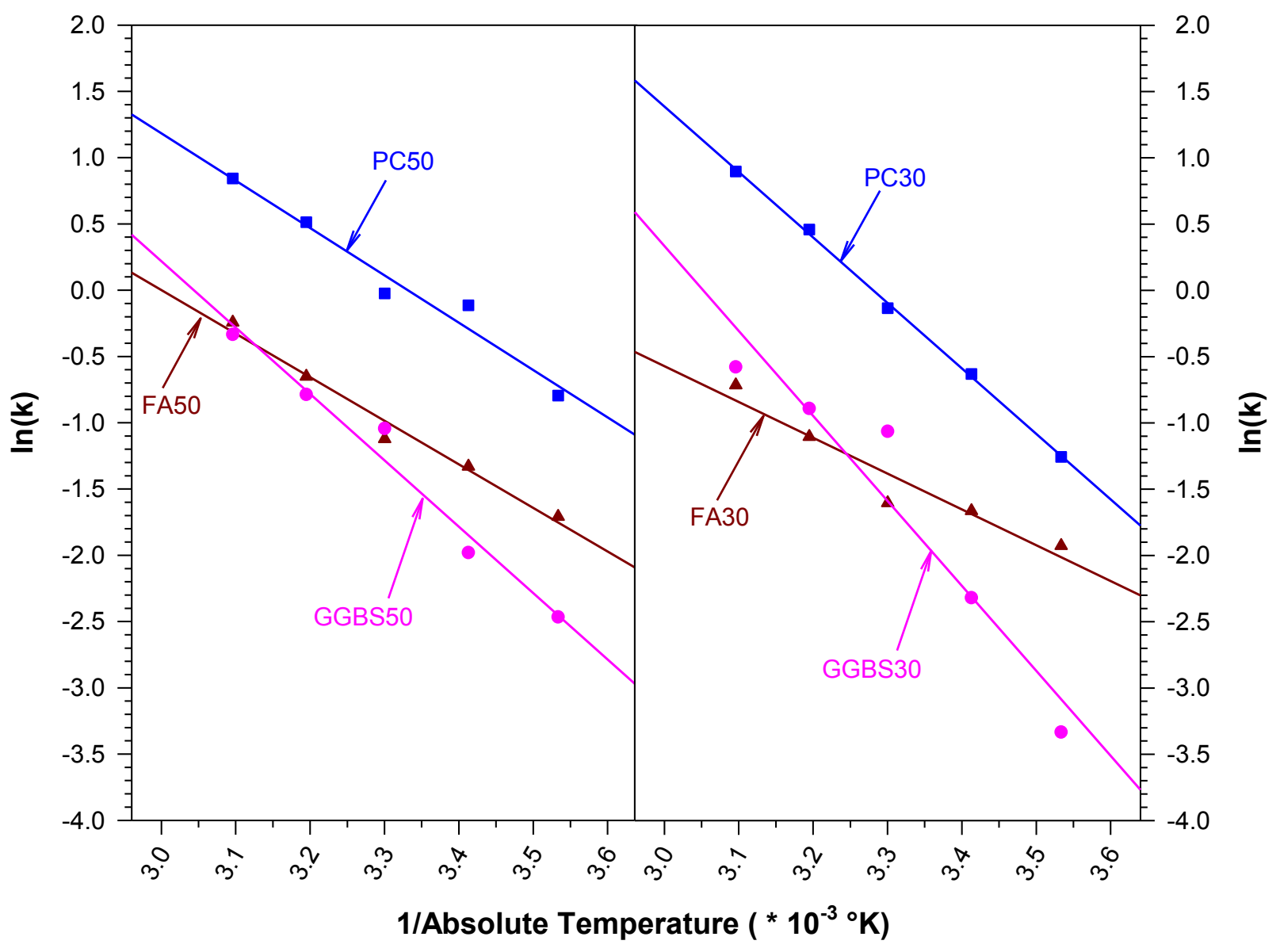
a) $50 \mathrm{MPa}$ Strength
b) $30 \mathrm{MPa}$ Strength

Figure 8: $\quad \ln (k)$ against $1 / T_{\text {abs }}$ for mortars. 


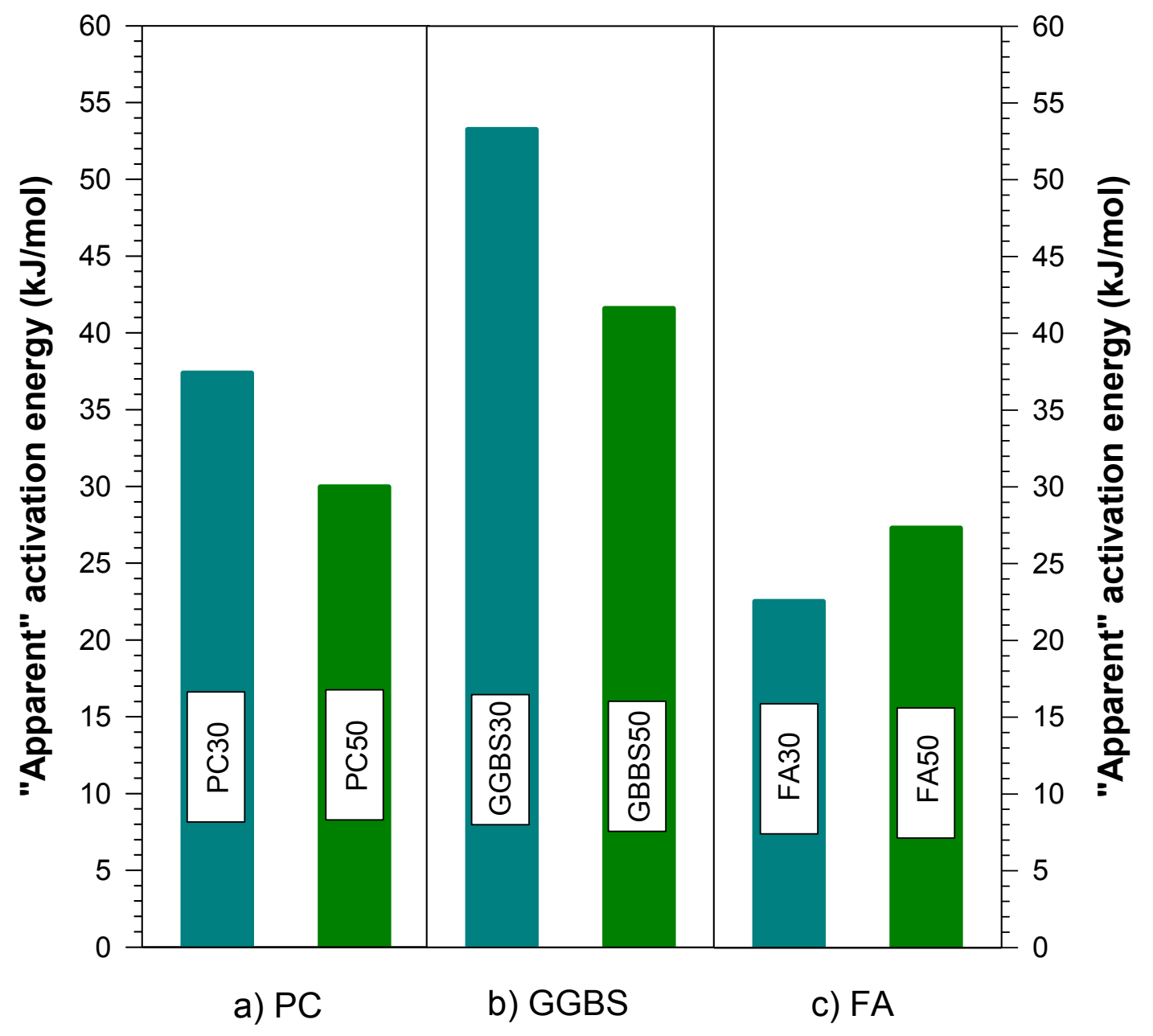

Figure 9: "Apparent" activation energies for PC, GGBS and FA mortar mixes. 


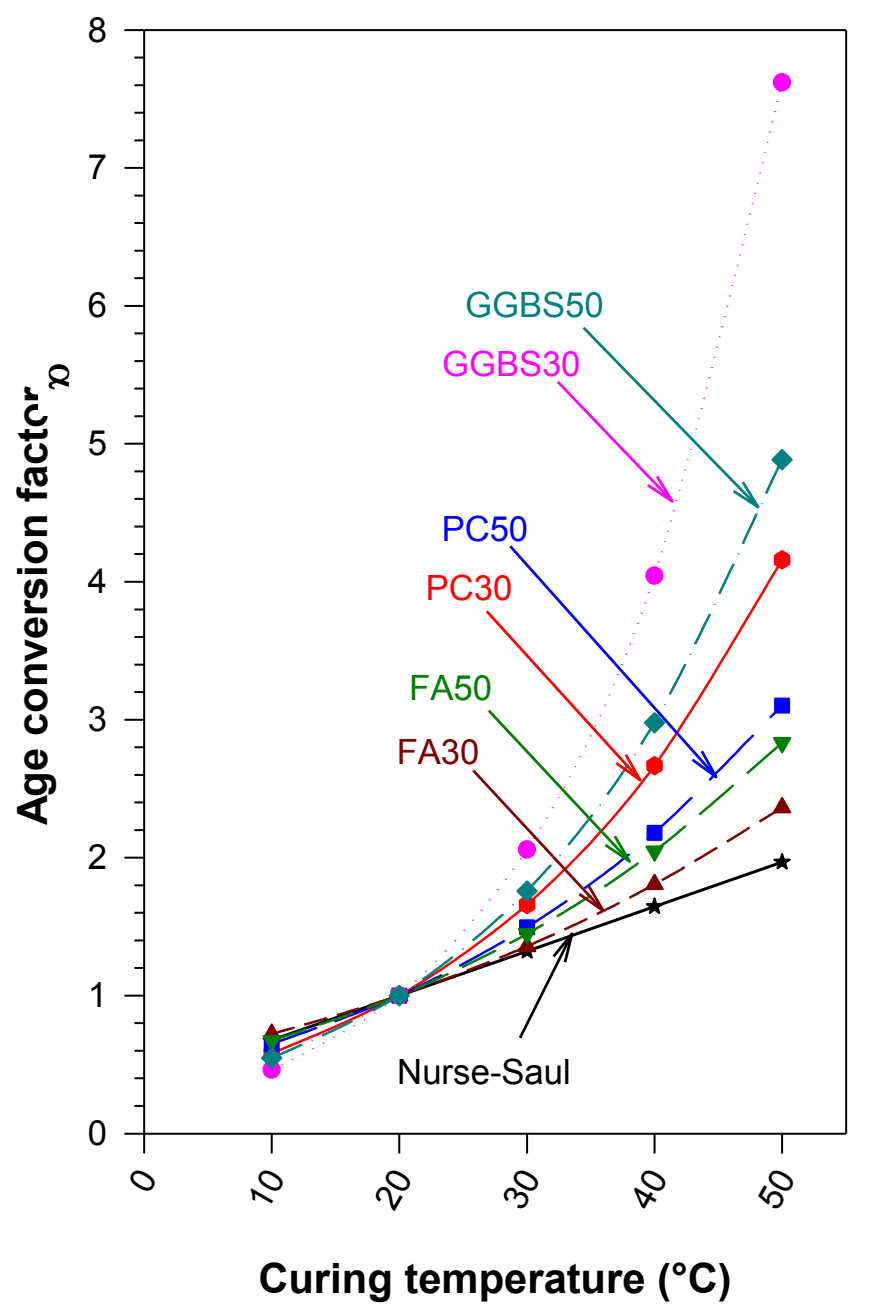

Figure 10: Effect of curing temperature on age conversion factor.

The age conversion factors for different curing temperatures were calculated from Equation 6 and the rate constant values shown in Table 3 were used with Equation 8. The reference temperature was taken to be $20{ }^{\circ} \mathrm{C}$. The age conversion factors increase exponentially with temperature. The linear relationship for the variation of $k$ with temperature assumed by the Nurse-Saul model is inadequate to describe the temperature sensitivity of particularly GGBS. The deviation from linear relationship of the age conversion factor with temperature is greater for GGBS followed by PC and FA. This indicates that the sensitivity of GGBS to temperature is higher than PC which in turn is higher than FA. 
Table 4 shows "apparent" activation energy values found in the literature and these have been plotted in Figure 11. "Apparent" activation energy values for neat Portland cement (CEM I or Type I) seem to be in the range from 30 to $50 \mathrm{~kJ} / \mathrm{mol}$, but there are some exceptionally high values above $60 \mathrm{~kJ} / \mathrm{mol}$. Partial cement replacement with GGBS seems to increase the "apparent" activation energy as the replacement level increases. There is only a limited number of values for "apparent" activation energies for FA mixes in the literature. The ones obtained from this work appear to indicate that partial cement replacement with FA will decrease the "apparent" activation energy. 
Table 4: "Apparent" activation energies from literature based on compressive tests on concretes/mortars.

\begin{tabular}{|c|c|c|c|c|c|}
\hline $\begin{array}{c}\text { Cement } \\
\text { type }\end{array}$ & GGBS/FA level & $\mathbf{w} / \mathbf{b}$ & $\begin{array}{c}\text { "Apparent" activation } \\
\text { energy }[\mathrm{kJ} / \mathrm{mol}]\end{array}$ & Source & Year \\
\hline CEM I & \multirow{12}{*}{$\begin{array}{c}\text { Neat Portland cement } \\
{[100 \% \mathrm{PC}]}\end{array}$} & 0.66 & $37.4^{\#}$ & Results from current study & 2016 \\
\hline Type I & & 0.6 & $48.0^{+}$and $43.6^{\#}$ & Carino \& Tank (1992) & 1992 \\
\hline CEM I & & 0.46 & $29.7^{\#}$ & Results from current study & 2016 \\
\hline CEM I & & 0.45 & $39.3^{\#}$ & Hatzitheodorou (2007) & 2007 \\
\hline Type I & & - & $42.0^{\#}$ & Carino (1981) & 1981 \\
\hline Type I & & - & $41.0^{+}$and $44.0^{\#}$ & Carino (1984) & 1984 \\
\hline CEM I & & 0.6 & $34.8^{\#}$ & Barnett et al. (2006) & 2006 \\
\hline CEM I & & 0.4 & $35.1^{\#}$ & Barnett et al. (2006) & 2006 \\
\hline CEM I & & 0.26 & $32.9^{\#}$ & Barnett et al. (2006) & 2006 \\
\hline CEM I & & 0.51 & $36.2^{\#}$ & Turru'allo (2013) & 2013 \\
\hline CEM I & & 0.33 & $28.9^{\#}$ & Turru'allo (2013) & 2013 \\
\hline Type I & & 0.45 & $61.1^{\#}$ and $63.6^{+}$ & Carino \& Tank (1992) & 1992 \\
\hline Type I & \multirow{2}{*}{$20 \% \mathrm{FA}$} & 0.45 & $33.1^{\#}$ and $30.0^{+}$ & Carino \& Tank (1992) & 1992 \\
\hline Type I & & 0.6 & $36.6^{\#}$ and $31.2^{+}$ & Carino \& Tank (1992) & 1992 \\
\hline CEM I & \multirow{2}{*}{$30 \% \mathrm{FA}$} & 0.35 & $27.3^{\#}$ & Results from current study & 2016 \\
\hline CEM I & & 0.53 & $22.5^{\#}$ & Results from current study & 2016 \\
\hline CEM I & \multirow{5}{*}{$20 \%$ GGBS } & 0.25 & $36.8^{\#}$ & Barnett et al. (2006) & 2006 \\
\hline CEM I & & 0.32 & $43.5^{\#}$ & Turru'allo (2013) & 2013 \\
\hline CEM I & & 0.39 & $35.2^{\#}$ & Barnett et al. (2006) & 2006 \\
\hline CEM I & & 0.48 & $39.4^{\#}$ & Turru'allo (2013) & 2013 \\
\hline CEM I & & 0.62 & $36.6^{\#}$ & Barnett et al. (2006) & 2006 \\
\hline CEM I & \multirow{5}{*}{$35 \%$ GGBS } & 0.25 & $46.8^{\#}$ & Barnett et al. (2006) & 2006 \\
\hline CEM I & & 0.33 & $44.0^{\#}$ & Turru'allo (2013) & 2013 \\
\hline CEM I & & 0.36 & $47.0^{\#}$ & Barnett et al. (2006) & 2006 \\
\hline CEM I & & 0.47 & $42.3^{\#}$ & Turru'allo (2013) & 2013 \\
\hline CEM I & & 0.58 & $47.1^{\#}$ & Barnett et al. (2006) & 2006 \\
\hline CEM I & \multirow{9}{*}{$50 \%$ GGBS } & 0.25 & $52.6^{\#}$ & Barnett et al. (2006) & 2006 \\
\hline CEM I & & 0.32 & $53.9^{\#}$ & Turru'allo (2013) & 2013 \\
\hline CEM I & & 0.38 & $48.0^{\#}$ & Barnett et al. (2006) & 2006 \\
\hline CEM I & & 0.44 & $44.1^{\#}$ & Turru'allo (2013) & 2013 \\
\hline Type I & & 0.45 & $42.7^{\#}$ and $44.5^{+}$ & Carino \& Tank (1992) & 1992 \\
\hline CEM I & & 0.46 & $41.6^{\#}$ & Results from current study & 2016 \\
\hline Type I & & 0.6 & $51.3^{\#}$ and $56.0^{+}$ & Carino \& Tank (1992) & 1992 \\
\hline CEM I & & 0.61 & $54.6^{\#}$ & Barnett et al. (2006) & 2006 \\
\hline CEM I & & 0.65 & $53.3^{\#}$ & Results from current study & 2016 \\
\hline CEM I & \multirow{5}{*}{$70 \%$ GGBS } & 0.25 & $57.9^{\#}$ & Barnett et al. (2006) & 2006 \\
\hline CEM I & & 0.30 & $54.7^{\#}$ & Turru'allo (2013) & 2013 \\
\hline CEM I & & 0.39 & $62.1^{\#}$ & Barnett et al. (2006) & 2006 \\
\hline CEM I & & 0.44 & $48.2^{\#}$ & Turru'allo (2013) & 2013 \\
\hline CEM I & & 0.52 & $58.8^{\#}$ & Barnett et al. (2006) & 2006 \\
\hline
\end{tabular}

${ }^{+}-$concrete, ${ }^{\#}-$ mortar 


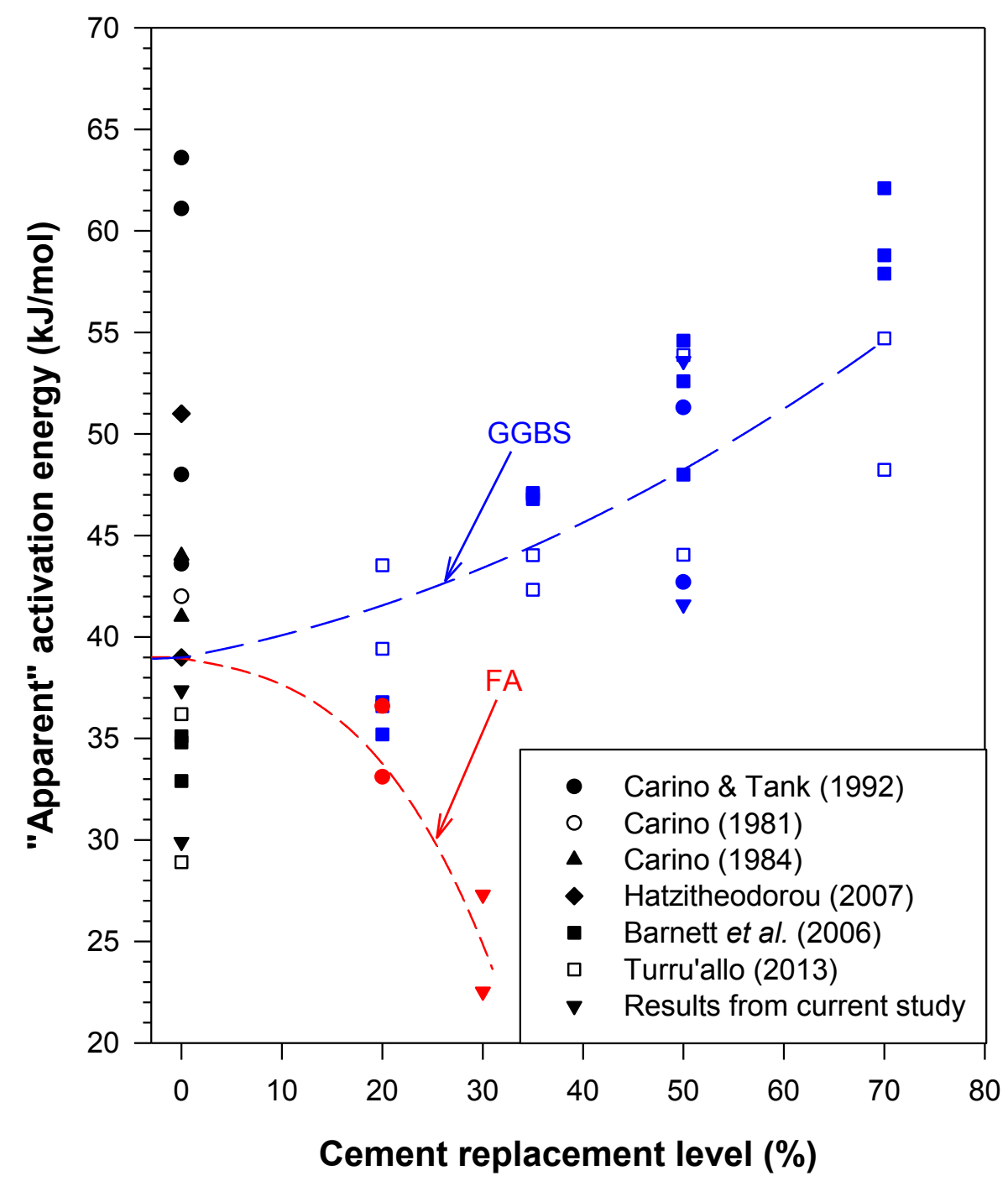

Figure 11: "Apparent" activation energies obtained from literature and current study.

\subsection{Applicability/accuracy of maturity functions for estimating the effect of elevated curing temperature on the strength development}

Several maturity functions exist in the literature (Saul, 1951; Parsons and Naik, 1985; Kjellsen and Detwiler, 1993; Babu and Rao, 1994; Chanvillard and D'Aloia, 1997; Adbel-Jawad, 2006; Liao et al., 2008; Galobardes et. al., 2015), which estimate the strength development of concrete under elevated and variable temperature conditions from its temperature history. These models use the experimentally determined strength-age relationship at a reference temperature (usually at $20{ }^{\circ} \mathrm{C}$ ) to estimate the 
strength at any other temperature. These models, however, were developed for Portland cement concrete. The temperature sensitivity GGBS and FA has been shown to be different from that of Portland cement (Soutsos et al., 2016; Soutsos et al., 2009; Boubekeur et al., 2014; Soutsos et al., 2013). It is therefore necessary to examine the applicability/accuracy of these maturity functions for concretes with GGBS and FA.

The Nurse-Saul function requires the temperature history, in this case the curing temperature, of the concrete in order to calculate the maturity index according to Equation 2. The equivalent age $t_{e}$ at time $t$ was calculated using Equation 4. The value of equivalent age obtained, $t_{e}$, was then substituted for $t$ in Equation 1 with constants $S_{u}$, $k$ and $t_{0}$, as previously determined for the strength data obtained for the mortar cured at $20{ }^{\circ} \mathrm{C}$ (see Table 3 ) and the estimated strength was thus obtained.

The Arrhenius function required the "apparent" activation energies which are shown in Figure 9. The equivalent age $t_{e}$ at time $t$ was calculated using Equation 7. The specified reference temperature, $T_{s}$, used was $293{ }^{\circ} \mathrm{K}\left(20^{\circ} \mathrm{C}\right) . T_{a}$ being the average temperature, in Kelvin, of mortar during time interval $\Delta t$ was none other than the curing temperature. The value of equivalent age obtained, $t_{e}$, was then substituted for $t$ in Equation 1 with constants $S_{u}, k$ and $t_{0}$, as previously determined for the strength data obtained for the mortar cured at $20^{\circ} \mathrm{C}$ (see Table 3). The estimated strength was thus obtained.

The Nurse-Saul function estimated the early age strengths of PC and FA mortars, even at the high curing temperature of $50^{\circ} \mathrm{C}$, much better than for GGBS, see Figure 12. However, it overestimated strengths beyond two days for PC and this increased with increasing age. This appears to be due to the inability of this function to account for the detrimental effect high early age temperatures have on later age strength. The estimates for the strength of FA mortars continue to be relatively accurate for longer ages as the "cross-over" effect (first reported by McIntosh (McIntosh, 1956)) is not as pronounced as for PC mortars and it does occur much later. The Nurse-Saul function underestimated the strength development of GGBS mortars even at early ages. This is because the Nurse-Saul function assumes that the concrete or mortar strength gain rate 
varies linearly with temperature irrespective of whether GGBS or FA is used or not. GGBS has been shown, see Figure 10, to be more temperature sensitive than PC and FA. This is also indicated by its higher "apparent" activation energy as compared to PC and FA - see Figure 9. The cross-over effect affects later age predictions, but these are much later than for PC mortars.

The strength estimates from the Arrhenius function, see Figure 13, appear to be affected very early-on by the cross-over effect of PC mortars. This is more than the Nurse-Saul function and this is because the Arrhenius function considers that the strength gain rate varies exponentially with temperature, as shown in Figure 10. If the strength estimates of the Arrhenius function are correct then the detrimental effect of high curing temperature starts from early age and is simply more pronounced in long term. The strength estimates are more accurate for FA mortars since the cross-over effect occurs at much later ages. The strength estimates for GGBS mortars are more accurate than those of the Nurse-Saul function because of the use of the "apparent" activation energies which account for the higher temperature sensitivity of GGBS than PC and FA. 


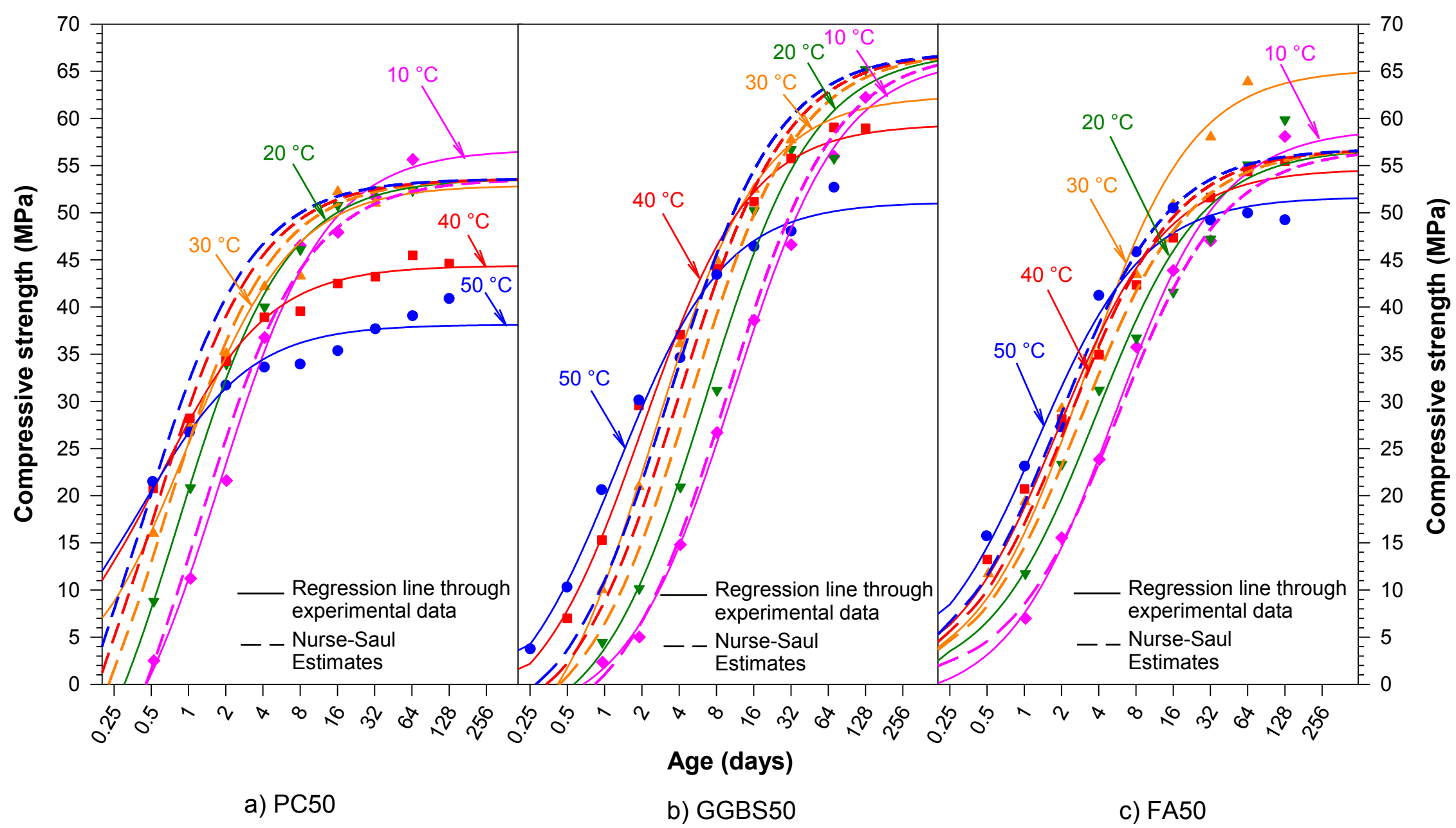

Figure 12: Nurse-Saul compressive strength estimates for 50 MPa compressive strength mortars. 


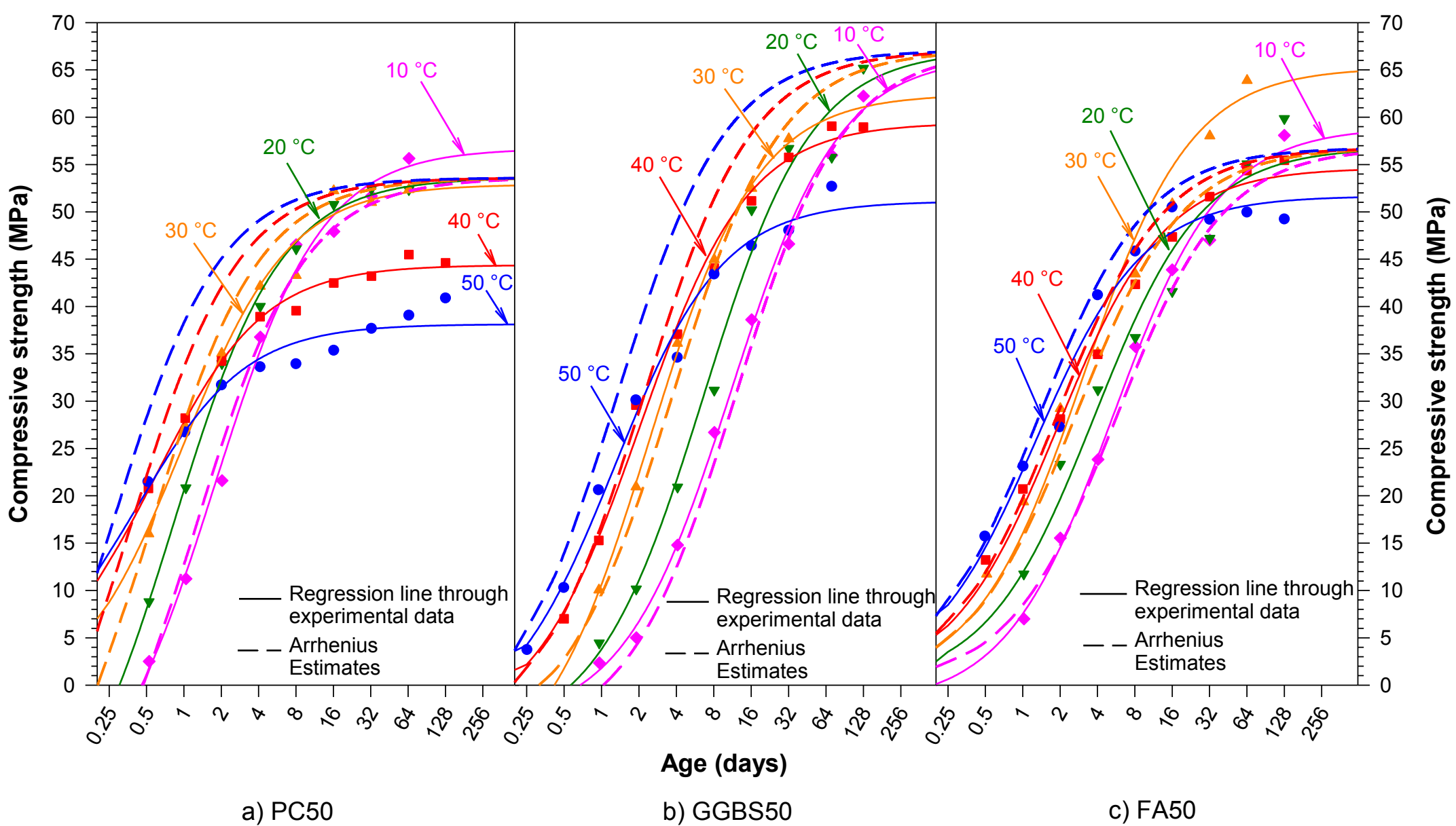

Figure 13: Arrhenius compressive strength estimates for $50 \mathrm{MPa}$ compressive strength mortars. 
The ratios of estimates to actual strength are shown in Figures 14 and 15. These confirm that the Nurse-Saul function underestimates the effect of high early age curing temperatures on the early age strength and this is most noticeable for the GGBS mixes. Strengths are overestimated at later ages because the Nurse-Saul function does not account for the long-term detrimental effect of high early age curing temperatures. The Arrhenius function on the other hand, overestimates even early age strength especially at the higher curing temperatures. This may be due to the detrimental effect starting from very early age at particularly the high curing temperatures. The Arrhenius function, similarly to the Nurse-Saul function, overestimates strengths at later ages. 


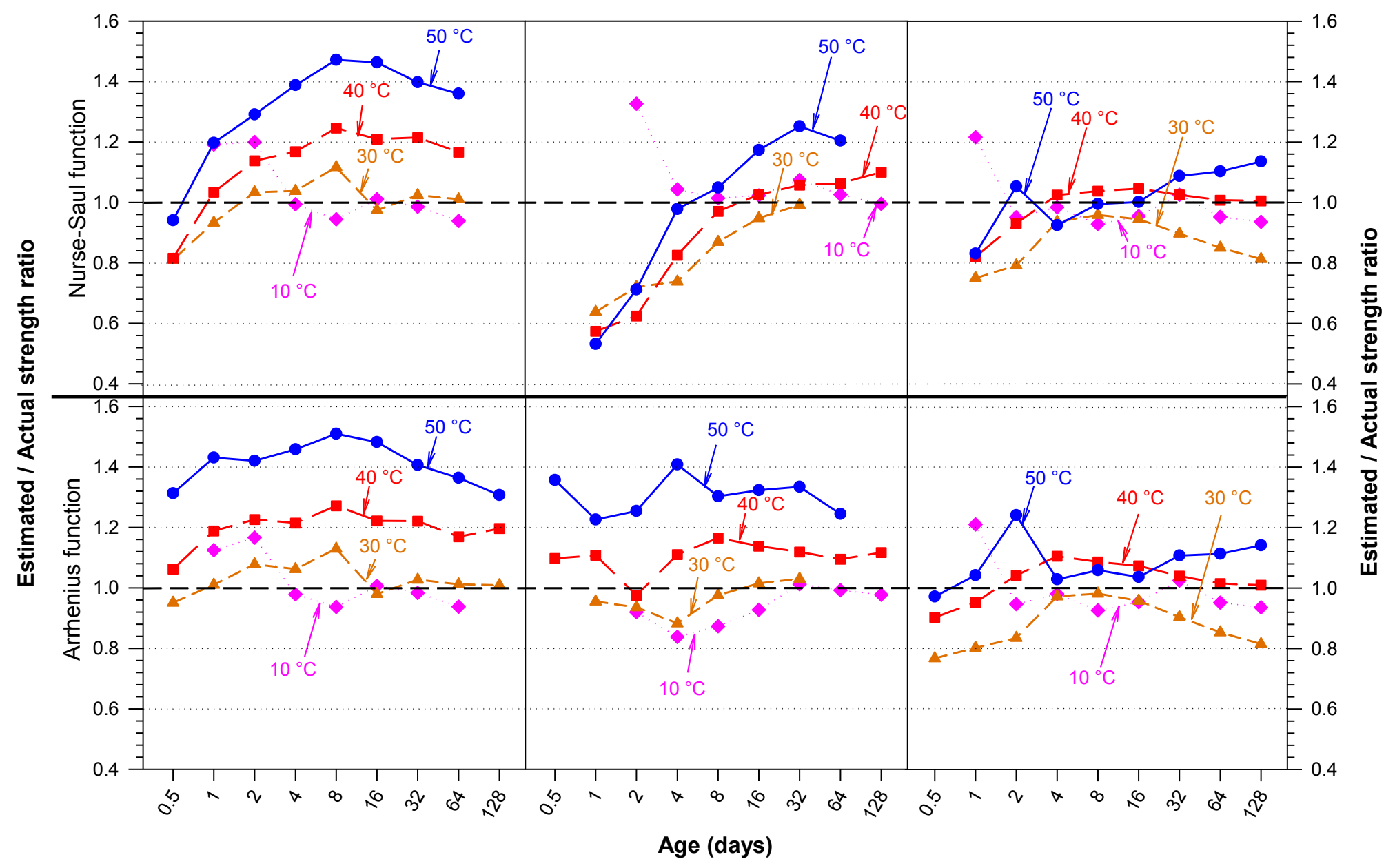
a) $\mathrm{PC} 50$
b) GGBS50
c) FA50

Figure 14: Estimated and actual strength ratios for 50 MPa mortars based on the Nurse-Saul and Arrhenius functions. 


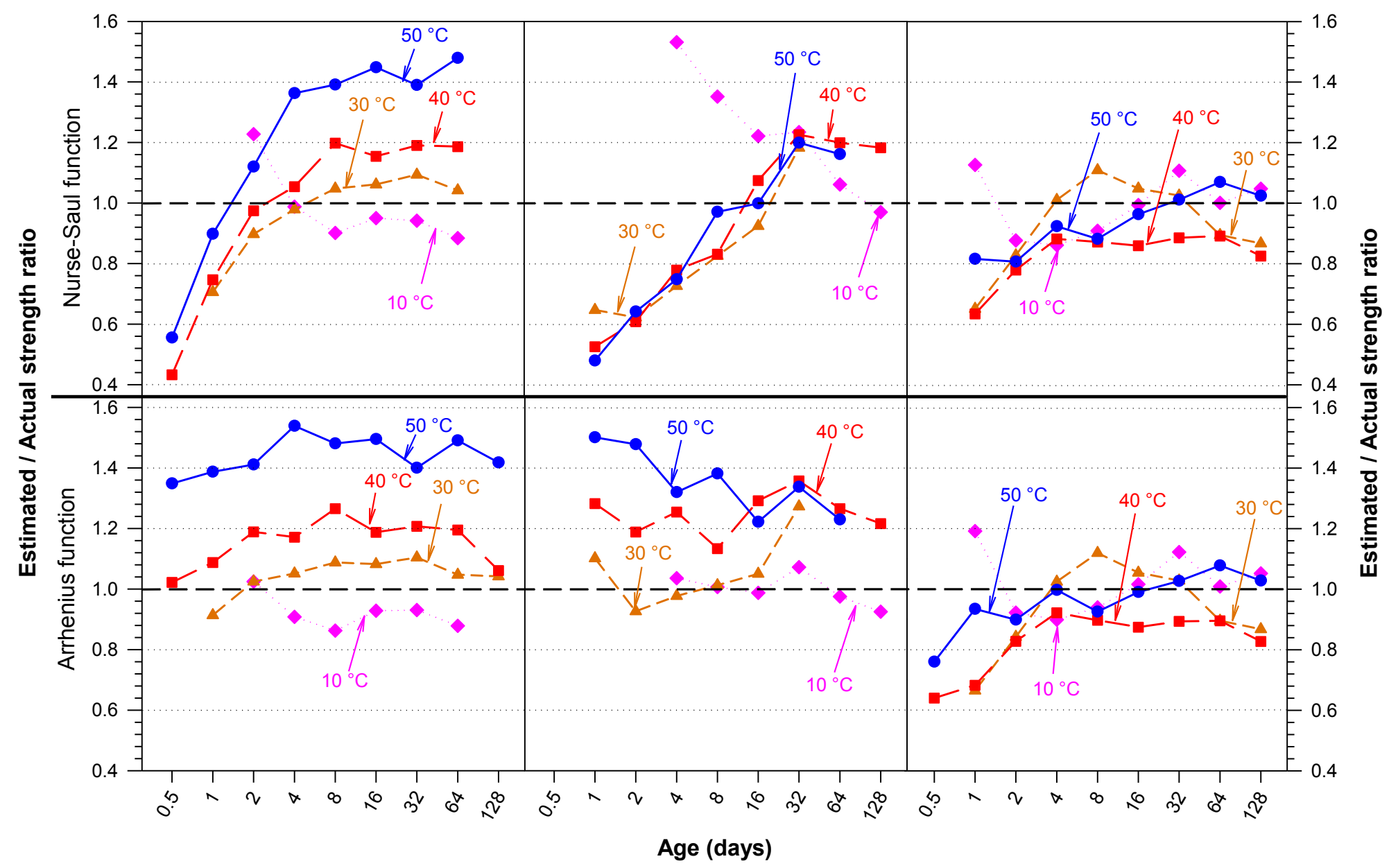
a) $\mathrm{PC} 30$
b) GGBS30
c) FA30

Figure 15: Estimated and actual strength ratios for 30 MPa mortars based on the Nurse-Saul and Arrhenius functions. 


\section{Conclusions}

The effect of temperature on the strength development of mixes with GGBS and FA has been investigated. The conclusions are:

- Strength development of "equivalent" mortars appears to be similar but not exactly the same as for the corresponding concretes. Nonetheless they can be used for determining the "apparent" activation energies for concrete mixes.

- High curing temperatures have a beneficial effect on the early age strength but a detrimental effect on the long term strength development. This confirmed previously reported findings.

- GGBS has been shown to be more sensitive to curing at high temperatures than PC and FA and this is reflected in its higher "apparent" activation energy.

- The Nurse-Saul function underestimates the early age strength development at higher curing temperatures whilst the Arrhenius function overestimates them. The reason for the latter appears to be the detrimental effect starting from a very early age. Both functions overestimate long term strengths as neither accounts for the detrimental effect of high curing temperatures on the ultimate compressive strength.

Work is continuing aiming to determine modification to the maturity functions in order to improve estimates of both early age and long term strength development with and without GGBS and FA. 


\section{Acknowledgements}

The majority of the experimental work described here was carried out by Dr A. Hatzitheodorou at the University of Liverpool as part of his PhD research. The authors are grateful to the School of Engineering, the University of Liverpool for the facilities provided and to the Engineering and Physical Sciences Research Council, UK (GR/R83880/01), for the financial support received for the equipment. The authors would like to thank Dr L.K.A. Sear at United Kingdom Quality Ash Association (UKQAA) for the extensive advice received during the project. 


\section{References}

Abdel-Jawad YA (2006) The maturity method: Modification to improve estimation of concrete strength at later ages, Construction and Building Materials 20, pp. 893-900.

ACI 233R-03 (2003) Slag Cement in Concrete and Mortar, Report of the ACI Committee 233, American Concrete Institute, Farmington Hills, Mich.

ASTM (2011) ASTM C1074-11 Standard practice for estimating concrete strength by the maturity method, West Conshohocken, Pennsylvania, USA, ASTM International.

Babu KG and Rao GSN (1994) Early strength behaviour of fly ash concretes, Cement and Concrete Research 24(2), pp. 277-284.

Barnett SJ, Soutsos MN, Bungey JH et al. (2007a) Fast-Track Construction with Slag Cement Concrete: Adiabatic Strength Development and Strength Prediction, $A C I$ Materials Journal, 104(4), pp. 388-396.

Barnett SJ, Soutsos MN, Millard SG et al. (2007b) Temperature Rise and Strength Development in Laboratory-Cast Structural Elements Containing Slag, American Concrete Institute SP-242: Ninth CANMET/ACI International Conference on Fly Ash, Silica Fume, Slag and Natural Pozzolans in Concrete (Malhotra VM (ed)), Warsaw, Poland, ISBN 978-0-87031-241-0, pp. 37-50.

Barnett SJ, Soutsos MN, Millard SG et al. (2006) Strength development of mortars containing ground granulated blast-furnace slag: Effect of curing temperature and determination of apparent activation energies, Cement and Concrete Research 36(3) pp. 434-440. 
Berndt ML (2015) Influence of concrete mix design on $\mathrm{CO}_{2}$ emissions for large wind turbine foundations, Renewable Energy 83, pp.608-614.

Bijen J (1996) Blast Furnace Slag Cement for Durable Marine Structures, Stichting BetonPrisma, Netherlands.

Boubekeur T, Ezziane K and Kadri E (2014) Estimation of mortars compressive strength at different curing temperature by the maturity method, Construction and Building Materials 71, pp. 299-307.

BSI (1992) BS 882:1992 - Specification for aggregates from natural sources for concrete, London, UK.

BSI (2011) BS EN 197-1:2011 - Cement. Composition, specifications and conformity criteria for common cements, London, UK.

BSI (2002) BS EN 12620:2002+A1:2008 - Aggregates for concrete, London, UK.

BSI (2005) BS EN 196-1-2005 - Methods of testing cement. Determination of strength, London, UK.

BSI (2012) BS EN 450-1:2012 - Fly ash for concrete. Definition, specifications and conformity criteria, London, UK.

Carino NJ (1981) Temperature Effects on the Strength-Maturity Relation of Mortar, Report No. NBSIR 81-2244.

Carino NJ (1984) The maturity method: Theory and application, Journal of Cement, Concrete and Aggregates (ASTM) 6(2), pp. 61-73.

Carino NJ and Tank RC (1992) Maturity Functions for Concretes Made with Various Cements and Admixtures, ACI Material Journal 89(2), pp. 188-196. 
Carino NJ (2004) The Maturity Method, In: Handbook on Nondestructive Testing of Concrete (Malhotra VM and Carino NJ (eds)), 2nd ed. CRC Press, pp. 5.1-5.47.

Chanvillard G and D'Aloia L (1997) Concrete strength estimation at early age: Modification of the method of equivalent age, ACI Materials Journal, 94(6), pp. $520-530$.

Escalante-García JI and Sharp JH (1997) Effect of temperature on the hydration of the main clinker phases in Portland cements: part H. Blended cements, Cement and Concrete Research 28(9), pp. 1259-1274.

Escalante-Garcia JI, Gómez LY, Johal KK et al. (2001) Reactivity of blast-furnace slag in portland cement blends hydrated under different conditions, Cement and Concrete Research 31(10), pp. 1403-1409.

Escalante-García JI, and Sharp JH (2001) The microstructure and mechanical properties of blended cements hydrated at various temperatures, Cement and Concrete Research 31(5), pp. 695-702.

Gambhi, ML (2013) Concrete technology, McGraw Hill Education, $5^{\text {th }}$ ed., pp. 431.

Galobardes I, Cavalaro S, Goodier CI et al. (2015) Maturity method to predict the evolution of the properties of sprayed concrete, Construction and Building Materials 79, pp. 357-369.

Golden K and Wong S (2016) Sustainable construction: Mountlucas windfarm, The Magazine of Concrete Society, 50(1), pp. 33-36.

Han N (2005) Maturity method, In: Reinhardt, H.W. and Grosse, C.U., Advanced testing of cement-based materials during setting and hardening, Final report of RILEM 
TC 185-ATC, RILEM Publications, pp. 277-296.

Hatzitheodorou A (2007) Insitu Strength Development of Concretes with Supplementary Cementitious Materials, $P h D$ thesis, University of Liverpool, UK.

Kjellsen KO and Detwiler RJ (1993) Later-age strength prediction by a modified maturity model, ACI Material Journal 90(3), pp. 220-227.

Liao W-C, Lee B . and Kang CW (2008) A humidity-adjusted maturity function for the early age strength prediction of concrete, Cement and Concrete Composites 30(6), pp. $515-523$.

Ling TC, Kou SC and Poon CS (2006) Precast architectural tiles produced by doublelayer casting method, Cement and Concrete Composites 66, pp. 73-81.

Malhotra VM (2006) Nondestructive tests, In: Significance of tests and properties of concrete and concrete-making materials (Lamond JF and Pielert JH (eds)), ASTM International; pp. 314-334.

McIntosh JD (1956) The effects of low-temperature curing on the compressive strength of concrete, In Proceedings of RILEM symposium on winter concreting, Session BII, Copenhagen: Danish Institute for Building Research.

Nurse RW (1949) Steam curing of concrete, Magazine of Concrete Research 1(2), pp. $79-88$.

Parsons TJ and Naik TR (1985) Early age strength determination by maturity, Concrete International 7(2), pp. 37-43.

Roy DM and Idorn GM (1982) Hydration, structure and properties of blast furnace slag cements, mortars and concrete, ACI Journal 79(6), pp. 444-457. 
Sanjayan JG and Sioulas B (2000)Strength of slag-cement concrete cured in place and in other conditions, ACI Material Journal 97(5), pp. 603-611.

Saul AGA, (1951) Principles underlying the steam curing of concrete at atmospheric pressure, Magazine of Concrete Research 2(6), pp. 127-140.

Soutsos MN, Barnett SJ, Bungey JH et al. (2005) Fast track construction with high strength concrete mixes containing ground granulated blast furnace slag, in: Proceedings of ACI Seventh International Symposium on High Strength/High Performance Concrete, (Russell, H.G. (ed)), ACI SP-228 1, pp. 255-270.

Soutsos MN, Barnett SJ, Millard SG et al. (2009) The Effect of Temperature on the Rate of Strength Development of Slag Cement, ACI SP-263 Slag cement concrete, (Aldea, C. M. (ed)), pp. 111-125.

Soutsos MN, Turu'allo G, Owens K et al. (2013) Maturity Testing of Lightweight SelfCompacting and Vibrated Concretes, Construction and Building Materials 47, pp. 118125.

Soutsos MN, Hatzitheodorou A, Kwasny J et al. (2016) Effect of in situ temperature on the early age strength development of concretes with supplementary cementitious materials, Construction and Building Materials 103, pp. 105-116.

Tank RC and Carino NJ (1991) Rate constant functions for strength development of concrete, ACI Material Journal 88(1), pp. 74-83.

Tang K, Millard S and Beattie G (2013) Technical and economic aspects of using GGBFS for crack control mitigation in long span reinforced concrete structures", Construction and Building Materials 39, pp. 65-70. 
The Concrete Society (2004) In situ concrete strength. An investigation into the relationship between core strength and standard cube strength, Concrete Society Project Report No. 3, The Concrete Society, Crowthorne, UK, 55 pp.

Thomas, M. (2013) "Supplementing cementing materials in concrete”, CRC Press.

Turu'allo G (2013) Early age strength development of GGBS concrete cured under different temperatures, $P h D$ thesis, University of Liverpool, UK.

Won JP, Kim HH, Lee SJ et al. (2015) Carbon reduction of precast concrete under marine environment, Construction and Building Materials 74, pp. 118-123.

Yikici TA and Chen H (2015) Use of maturity method to estimate compressive strength of mass concrete, Construction and Building Materials 95, pp. 802-812. 